Article

\title{
Tourists' Perceptions Regarding Traveling for Recreational or Leisure Purposes in Times of Health Crisis
}

\author{
Carmen-Mihaela Cretu ${ }^{1}$, Anca-Gabriela Turtureanu ${ }^{1, *}{ }^{(\mathbb{D}}$, Carmen-Gabriela Sirbu ${ }^{1}{ }^{10}$, Florentina Chitu ${ }^{2}$, \\ Emanuel Ştefan Marinescu ${ }^{3}$, Laurentiu-Gabriel Talaghir ${ }^{4,5}$ and Daniela Monica Robu ${ }^{6, *}$ (1) \\ 1 Faculty of Economic Sciences, Danubius University of Galati, 800654 Galati, Romania; \\ carmencretu@univ-danubius.ro (C.-M.C.); carmensirbu@univ-danubius.ro (C.-G.S.) \\ 2 Faculty of International Business and Economics, Bucharest University of Economic Studies, \\ 010374 Bucharest, Romania; florentina.chitu@stud.ase.ro \\ 3 Faculty of Communication and International Relations, Danubius University of Galati, 800654 Galati, \\ Romania; marinescuemanuel@univ-danubius.ro \\ 4 Faculty of Physical Education and Sport, Dunarea de Jos University of Galati, 800008 Galati, Romania; \\ Gabriel.Talaghir@ugal.ro \\ 5 Institute of Sport, Tourism and Service, South Ural State University, 454080 Chelyabinsk, Russia \\ 6 Faculty of Communication and International Relations, Press Department of Danubius University of Galati, \\ Danubius University, 800654 Galati, Romania \\ * Correspondence: ancaturtureanu@univ-danubius.ro (A.-G.T.); danarobu@univ-danubius.ro (D.M.R.); \\ Tel.: +40-733180176 (D.M.R.)
}

check for updates

Citation: Cretu, C.-M.; Turtureanu, A.-G.; Sirbu, C.-G.; Chitu, F.;

Marinescu, E.Ş.; Talaghir, L.-G.; Robu, D.M. Tourists' Perceptions Regarding Traveling for Recreational or Leisure Purposes in Times of Health Crisis. Sustainability 2021, 13, 8405. https:// doi.org/10.3390/su13158405

Academic Editors: Isabella Crespi and Alessandra Fermani

Received: 20 May 2021

Accepted: 17 July 2021

Published: 28 July 2021

Publisher's Note: MDPI stays neutral with regard to jurisdictional claims in published maps and institutional affiliations.

Copyright: (c) 2021 by the authors Licensee MDPI, Basel, Switzerland. This article is an open access article distributed under the terms and conditions of the Creative Commons Attribution (CC BY) license (https:/ / creativecommons.org/licenses/by/ $4.0 /)$.

\begin{abstract}
This study aimed to explore the perceptions of tourists regarding traveling for recreational or leisure purposes in times of health crisis. All areas of activity have been affected by the pandemic caused by the SARS-CoV-2 coronavirus (associated with a disease called COVID-19), and all countries are experiencing health crises. The tourism industry, together with its associated fields, experienced a decline during this period that is still difficult to assess. This study examined intentions to travel in the current conditions imposed by the health crisis. Various measures have been recommended or imposed by governments to control the spread of COVID-19. Travel has been significantly influenced by such measures. However, people have various travel needs, from shopping to work and leisure to exploration. The data were collected through an online questionnaire survey addressed to the active population in Romania. The application of this questionnaire coincided with the third wave of SARS-CoV-2 infections in Romania. The conditions related to the degree of incidence of infections in the respondents' areas and also the connection between the expression of the intention to travel and the protection conditions in the destination areas were analyzed. The entire study was based on office research, statistical analysis, case study methods, and analysis of empirical data obtained through the survey of the active population in Romania. The results explain the travel tendencies of Romanians in the following period. Fear of infection and perceived risk have significantly influenced travel behaviors, but intentions to travel for recreational or leisure purposes have been maintained. The results of this study could be useful in planning and rethinking the activities of the tourism industry in the coming period.
\end{abstract}

Keywords: COVID-19 pandemic crisis; tourism; travel intention; health; Romania; uncertainty

\section{Introduction}

Nothing special was announced at the beginning of February 2020; no one could have imagined what would happen in the coming months due to the COVID-19 pandemic and, in particular, that it would become a health emergency and at the same time a global economic emergency. It is an economic emergency that we could certainly compare with the crisis of 1929. On 11 March 2020, the WHO declared COVID-19 a global pandemic [1].

In the initial phase, the phenomenon was underestimated almost everywhere. All economic sectors were affected [2]. Tourism is certainly one of the sectors that has suffered 
the most dramatic impact, the main cause being the lack of mobility of people, which is an essential condition for protection against COVID-19.

The current tourism context is very delicate, but tourism has always shown great adaptability and resilience in times of crisis. The unfortunate events related to the attacks of 9/11 [3], SARS in Asia [4], international terrorist attacks [5], and the global financial crisis of 2008 [6] are all examples of how dramatic situations have affected the behavior and habits of tourists, but they also highlight how the tourism market has succeeded in always coming back and growing over time. It is clear that COVID-19 was an asymmetric shock for tourism, but also for all individuals. Previous crises, although much less severe, have led to changes and the introduction of new business models. For example, the crisis caused by the attacks on the Twin Towers on 11 September 2001 led to the tightening of security measures, which have been strengthened. The financial crisis of 2008 led to the creation of the common economy and new tour operators with non-existent products and business models. It is still too early to understand the magnitude and depth of the changes that will take place in the consumption modes and priorities of post-COVID tourists, but there will certainly be a transformation.

At the time of this research, the whole world was already in contact with the third wave of coronavirus infections. There have been more than 132 million cases and more than 12.8 million deaths, and more than $80.6 \%$ of infected people have already been cured worldwide [7].

International, regional, and local travel restrictions immediately affected national economies, including the tourism industry, e.g., international travel, domestic tourism, day trips, and diverse segments such as air transport, cruises, public transport, accommodation, cafes and restaurants, conventions, festivals, meetings, and sporting events. As international air travel has rapidly slowed as a result of the crisis and many countries are imposing travel bans, closing borders, or introducing quarantine periods, international and domestic tourism has plummeted during the health crisis.

After a difficult year in 2020, countries tightened travel restrictions in response to the new wave of COVID-19 infections, and the global tourism industry suffered further failures in 2021. According to the latest World Tourism Organization (UNWTO) [8] report, all regions of the world continued to see a significant decline in tourists in the first month of 2021. Mandatory testing, quarantine, and, in some cases, complete border closures have prevented the resumption of international travel. In addition, the speed and distribution of vaccinations were lower than expected, thus further delaying the recovery of the tourism industry.

The changes in international tourist arrivals have been dramatic: while in January 2019 there was a $4 \%$ increase globally, in 2020 there was a decrease of $73 \%$, and January 2021 brought a decline of $87 \%$. The UNWTO Secretary-General said: "2020 was the worst year on record for tourism".

According to current trends, the UNWTO [8] predicts that for the first quarter of 2021, the number of international tourists will decrease by about $85 \%$ compared to the same period in 2019. Compared to the pre-pandemic level, this means a reduction of about 260 million international tourists.

The future trend of the spread of the virus, the uncertain moments of reopening borders, and the different policies adopted by states and by regions within states make forecasting very complicated and uncertain. The tourist demand of each country tends to manifest itself within its borders.

In Romania, the evolution of the COVID-19 epidemic followed the trend of the European Union, with the first confirmed case of infection registered on 26 February 2020. By 18 March 2020, 261 cases of COVID-19 infection had been confirmed, and between 26 February and 5 April 2020, 4051 cases were confirmed, of which 181 resulted in deaths. Most of the infections ( $49 \%$ ) were cases of importation, and they became direct contacts for the rest of the infected. The introduction of a state of emergency on 15 March 2020 greatly contributed to limiting the spread of SARS-CoV-2 infection among the population. With the 
establishment of the state of emergency, various economic branches began to decline. The first to be affected were health and education. Starting with the establishment of the state of emergency and with the traffic restrictions imposed, the hotel, restaurant, and cafe/catering (HoReCa) industries entered into a dramatic decline.

During all this period, we have not lost sight of the close connection that links the tourism industry to the environment, most of the attractions being natural resources, whether we are talking about seaside tourism or mountain tourism or the attraction of winter sports, etc. It has been shown that hedonic values appear to be significantly and negatively linked to a range of environmentally relevant attitudes, preferences, and behaviors [9]. The literature on pro-environmental behavior suggests that the values of self-transcendence, such as utility, encourage sustainable choices [10], while values of selfimprovement, such as hedonism, discourage them for the most part [11]. It is the quality of the environment that seems to occupy a top place in the perception of future travels.

\section{Literature Review}

The tourism industry is seen in terms of its ability to attract tourists and as a platform for economic growth and sustainable development. The period since the onset of the health crisis caused by the SARS-CoV 2 virus has affected all human activities, but none is affected in the same way as tourism [12].

The literature review is analyzed from two perspectives: on the one hand, the literature that reflects the impact of the pandemic crisis caused by the SARS CoV-2 virus on the entire tourism industry, and on the other hand, the specialized literature that addresses the perception of tourists on traveling during and after the health crisis.

\subsection{The Impact of the Pandemic Crisis Caused by SARS-CoV-2 Virus on the Tourism Industries}

Facing exceptional circumstances, the tourism industry reached a point of interruption of normal activity on a scale never seen before, as borders are closed and more and more travel restrictions were imposed according to Figure 1. At the beginning of 2021, 32\% of countries had closed borders and $34 \%$ were partially restricted destinations.

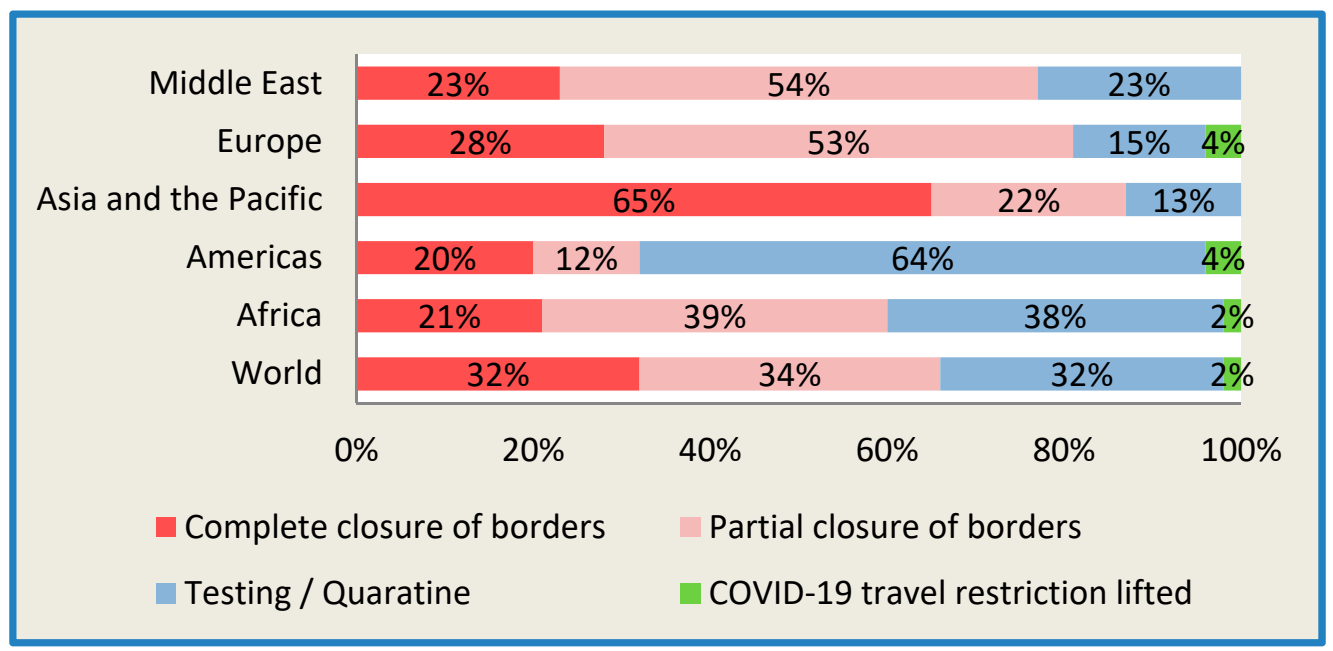

Figure 1. Regional breakdown of travel restrictions as of 1 February 2021 [13]. Source: Data compiled by UNWTO as of 1 February 2021. Page 14. COVID-19 RELATED TRAVEL RESTRICTIONS A GLOBAL REVIEW FOR TOURISM. 14. https: / / webunwto.s3.eu-west-1.amazonaws.com/s3fspublic/2021-03/210309-Travel-Restrictions.pdf, accessed on 15 April 2021.

The complete closure of borders means that all air, land, and sea borders are closed for international tourism purposes. Partial border closure means that some of the different types of borders (air, land, or sea) are closed, but not all: for example, land borders are closed, while travelers can arrive by air [13]. As a result of the limitation of international 
tourist traffic by imposing restrictions on the border, either by total or partial closure, or by testing or quarantine, all links in the hospitality value chain have been affected [14] The impact of the canceled events and the closure of accommodations and attractions had an immediate impact on other sectors that were largely dependent on tourism, such as catering and laundry services [15]. Restaurants also had to close, although in some countries the shift to home delivery allowed them to continue operations.

All countries of the world and all tourist destinations suffered as a result of the rapid evolution of the pandemic. In Romania, a country with a population of 19.1 million inhabitants, more than 1 million cases of people infected with the new coronavirus (COVID19) were confirmed, around 885,000 were declared cured, and 28 deaths were declared by the end of April. The most cases were recorded on November 18, when 10,268 infections were confirmed within $24 \mathrm{~h} \mathrm{[16].}$

With the declaration of the state of emergency and the limitation on movement, many companies belonging to the different tourist sectors, or related to them, immediately experienced a major liquidity crisis due to the almost total lack of demand.

As in other states, Romania faced an unprecedented reality without a vaccine for preventing the disease and limited available medical interventions. The impossibility of developing in a very short time effective antivirals for the treatment of patients or a vaccine for immunization against a newly discovered virus led to the development of nonmedical measures (the main means of response to limit and control diseases). In response, various forms of non-pharmaceutical interventions (NPI) intervened, including blocking (housing isolation, voluntary/required quarantine), social distancing (vulnerable or entire populations), closure of schools/universities and non-essential businesses/jobs, and cancellation or postponement of events (i.e., sports conferences and competitions, national and international fairs, concerts and festivals, and even debates and political elections).

Romania was to host important events in the summer of 2020, such as some of the matches of the European Football Championship in 2020 (which was estimated to have about 200,000 spectators, $35 \%$ of whom could have been foreigners). Very important music festivals for the Romanian tourism industry were also postponed. The four largest music festivals in Romania, namely Untold, Electric Castle, Neversea, and Summer Well, had in 2019 over 800,000 visitors. In addition to the money raised by festival organizers, these events bring income to related businesses, such as hotels and restaurants [17].

The demand for travel has been discouraged since March 2020; all potential travelers have had their lives changed. Many were restricted by traffic restrictions, lost their jobs, or had the opportunity to telework. Social structures are already being revolutionized by the introduction of artificial intelligence into industry and society, and the legal framework is not yet ready to fully absorb the impact [18]. Jobs where teleworking is possible target bank employees, IT and communications employees, and a large number of managers and experts. However, other occupations require presence at the workplace, such as salespeople, cleaning or health workers, and the HoReCa field. While for some companies the adoption of telework is not new, COVID-19 has accelerated this process and extended it to several companies that did not have previous experience [19]. For the hospitality industry, it has been proven that telework does not seem to be a solution. Tourist services, as with most services, are characterized by immateriality, by the impossibility of storage, and by the inseparability of the travel service provider. For the hospitality sector, there is no possibility to provide remote work. That is why the HoReCa domain is considered to be disadvantaged from this point of view.

Certain sectors of the tourism industry will never be able to return to the pre-crisis level, especially due to the digital transformation that was already under way and has been accelerated by the created situation. An example is the MICE sector (meetings, incentives, conferences, and exhibitions), where virtual meetings have shown that you do not need international travel to attend conferences.

In addition to travel bans, it also contributed to the limitation of travel and the decrease of the population's income [20]. The massive loss of jobs and implicitly of the incomes had 
a dramatic impact on the tourist demand during the important summer season of 2020 in the northern hemisphere and on the winter season of 2021 in Europe.

The world economy is experiencing one of the worst economic crises since the Great Depression (1929-1933), and the forecasts of economists place its impact even beyond the magnitude of that recorded during the Great Depression. The Romanian economy could not remain unaffected by this impact, given its dependence on global economic mechanisms and its integration into European and global value chains. The Romanian economy has registered one of the largest contractions in Europe of 12.3\% (according to Eurostat), being surpassed only by the states whose GDP is based on tourism (Spain, Croatia, Greece, Hungary, Portugal, France, Italy).

One of the consequences of this crisis is the disruption of transport, and it is not only about urban transport [21,22] but also about transport that ensures the mobility of national and international travelers. During health crises, people perceive a higher risk for all types of travels and avoid going to places where they perceive a medium to high risk, and congestion at airports or stations coupled with travel restrictions imposed substantial reductions in the frequency of all types of traveling [23] and in the use of all types of means of transport $[24,25]$.

About $58 \%$ of tourists reach their destination by air, and stopping air traffic has also created a massive negative effect [26] on the tourism industry [27]. The International Air Transport Association (IATA) [28] report shows that total demand for the year decreased by $65.9 \%$ compared to 2019 , by far the sharpest decline in air traffic in all of history. The IATA forecast for 2021 is in favor of an increase of $50.4 \%$ compared to 2020 demand, which would bring the aviation industry to $50.6 \%$ of 2019 levels. At the end of an extremely difficult year, all airports in Romania have reported much lower traffic figures than in previous years. In total, in 2020, a little over 7.1 million passengers passed through all airports in Romania-compared to 23.23 million in 2019, which means a decrease of almost 70\% [29].

The uncertainty generated by the lack of full knowledge of the evolution of the pandemic in the near future directs travel motivations in another direction $[17,30]$. The change of desire [31] and motivation to travel [32] brought major changes to Romania in the directions of the development of some types and forms of tourism [33,34]. Tourism is a complicated psychological process based on complex motivations, and the impact of SARS-CoV-2 is also psychological in nature [35].

The pandemic period raised questions about the sustainability of tourism sectors, such as cruises and aviation, especially as some European countries move towards an ecological recovery. Cruise tourism could be considered a niche development opportunity for Romania. Romania could benefit from cruises on the Danube or the Black Sea [36], although cruise ships have not proved being very safe in spreading the COVID-19 virus [37]. At the heart of the tourism industry is the concept that this industry is good for society in general, providing jobs and tax revenue to the state [38]. Thus, the pandemic could be considered an opportunity for more sustainable reconstruction of businesses for the benefit of people and the planet, as an opportunity to maximize the positive impact of tourism on the environment, and as a possibility for reducing its negative effects [39].

International travel bans and the feeling of insecurity associated with flights and airports will make tourism options gear towards the domestic market. More people are expected to generate a real flow to their countries of origin, supporting local economies by exploring their own cities [40]. Locations in unfamiliar areas have the opportunity to increase their exposure [41], and less frequented tourist destinations can benefit from demand, given the preference for less crowded places [42].

\subsection{Tourists' Perception of Travel in the Health Crisis and Beyond}

This study aims at analyzing the perception of travel [43] as a process of knowing and understanding the tourist phenomenon, especially in this pandemic context, as well as the intention of citizens, as a desire or planning a trip [40]. 
Most of the time, speaking of tourism, both perception and intention are processes that we can analyze together, as they are complementary [44]. Initially, in the collective mind, there is the intention to travel, to later perceive the conditions of travel, and to analyze the rules and restrictions of travel during this period [45], and this is primarily due to the fact that tourism falls into the category of intangible, heterogeneous, inseparable, perishable services, and it is considered a product that cannot be consumed before its experience [46].

Based on various analyses [47], it is clear that research centers, institutions, and trade associations converge in anticipation of future trends based on the perception of travelers [40,48].

When the tourism industry is not affected by crisis, the perception of the tourist destination plays an important [49] and promoting destinations [50], but in times of crisis, travelers have more realistic perceptions of risk at the destination, and thus, the destination acquires other values [51]. The perceptions "a priori", "in situ", and "a posteriori", as they are described by different authors [50,52], are affected in times of crisis by conjuncture factors [53]. The same tourist destination is perceived differently under the conditions of an economic crisis [40] or a health crisis [54], and a completely different perception in case of a terrorist crisis [55].

The perception of tourists on the image of the destination is affected by the general impression of the destination, and it is related to the expected benefits and consumption value [56]. The perception of the image of a tourist destination is a comprehensive impression formed by the perceptions, emotions, points of view, and perspectives of tourists about destinations $[43,57,58]$ In the recent years, the process of forming and projecting the perception of the image of tourist destinations has always been the main focus of analysis on specific destinations [57].

There are studies that have examined the perception of the risk of travelers following a health crisis [59-61] (SARS, H1N1, Ebola) prior to this crisis caused by SARS-CoV-2. However, it is not yet known how COVID-19 [62], a pandemic that overcomes all former tourism crises, will affect the perception of travelers' risks and influences the behavior of traveling throughout a period of time [63,64].

The onset of the COVID-19 pandemic has affected tourists' perceptions of travel [65], and it will change the way people travel for another long period of time, especially in terms of pace, intensity, and spontaneity of travel [63].

\section{Materials and Methods}

This paper aims at analyzing the perception of travel in the next period in the current pandemic context. The major challenge of the situation is that accessing services in the travel and tourism industry is an extremely social experience, with travelers interacting with numerous operators and indirect service providers (agencies, hotels, restaurants, etc.) [66].

In order to fulfill the objective of the research, a series of methods and techniques are combined, namely office research, statistical analysis, case study method, and analysis of empirical data obtained through the survey among the active population in Romania.

In order to analyze the tourists' perception regarding trips for tourist purposes during a health crisis, it was necessary to administer a questionnaire among the population in order to identify the research results.

The sampling of the selected persons was based on the non-probabilistic method. This model involves the inclusion of accessible and available cases in the sample $[67,68]$. This type of sampling is usually used in social research and falls within the scope of this paper [69].

The basis of this sample is the "Snowball" method suitable for this research [70]. The "Snowball" method was chosen because the research sample grows to a size considered sufficient by the researcher. This method satisfied the needs of the study given that many regions of the country were in lockdown, and communication between people was often possible only by phone and online. The "Snowball" method involves the use of initial 
units to generate additional units, and the operation resembles the rolling of a snowball, which has a similar effect, the sample becoming larger. This method allowed for the creation of a sample to meet the requirements under the restrictive conditions imposed by the pandemic crisis. Convenience sampling was not addressed. Although it collects market research data from a conveniently available group of respondents and is prompt in response, it has a major disadvantage over the "Snowball" method in that it does not allow for additional entries in the main research, which are necessary for the study. In the first phase, a series of subjects were identified who met the conditions for inclusion in the research sample. The respondents from the initial group were chosen from four different areas of the country, and they met the inclusion criteria in the active population. In the conditions of the sanitary crisis of Romania, in this study, in the third wave of infections with the SARS-CoV-2 virus, subjects from the groups of acquaintances who met the inclusion conditions were approached. This phase coincided with the identification of cases of interest from people who knew other people, who knew other cases, thus providing additional information. In the second phase they were asked to look for other subjects who met certain explicit criteria (age, level of education, belonging to certain groups of concerns, etc.) [71]. The questionnaire also was applied online due to the safety criteria imposed by the crisis generated by SARS-CoV-2 virus.

To determine the sample size, we used the Slovin or Yamane formula [72]. This formula is a very general equation used when we can estimate the population but do not have clear clues about how a certain population behaves.

The questionnaire contains 16 questions and was completed in Google Forms. It has been distributed on various online platforms. The questionnaire is addressed to the active population in Romania. The active population in Romania between the ages of 16 and 65 was 9,027,000 people at the end of 2020 . For an error of $4 \%$, the sample size should be 624 people. By sampling with the "Snowball" method and distributing the questionnaires electronically, we received 672 valid answers, which means an error of 0.385 with a confidence level higher than $95 \%$.

The questions in the survey questionnaire were asked so that tourists' perception of travel for tourism purposes during the health crisis could be recognized. The questions of the questionnaire follow a flow idea, so first of all, there were questions on checking if the respondents used to travel for tourism. These questions were addressed to travel habits, namely their rhythm (weekly, monthly, once a few months/quarterly, once a year, and once every several years) or favorite destination (in the country of residence or abroad). The following questions focus on both the perception of travel conditions and the restrictions imposed in the context of the pandemic. Then, the following questions clarify the pandemic context that underlies the perception of a trip in the near future. Considering the rapid change, from one day to the next, of the restrictions imposed by the health crisis, where necessary, the questions have in their content: "When you answer these questions ... ".

In this paper, as a method, we have used descriptive statistical analysis that summarizes the data of the population responding to the questionnaire applied to "Tourists' perceptions of travel for recreational or leisure purposes in times of health crisis" to describe the basic characteristics of the data obtained expressed numerically in a percentage or graphically. This type of analysis was useful in terms of describing categorical data by reducing a lot of data into a more concise result. Along with this descriptive method, we have also applied the methods of average, score, and " $t$-Test: Paired Two Sample for Means".

\section{Results}

The subject of the study was Tourists' perceptions of travel for recreational or leisure purposes during a health crisis caused by the SARS-CoV-2 virus. The research had 672 respondents from Romania among the active population aged between 16 and 65 years. The research was conducted from 15 March to 15 April 2020 using the method of a diagnostic survey and a questionnaire form submitted online. We should mention that during this period, 
Romania was at the peak of the third wave of COVID-19 infections. Many localities in the country were subject to restrictions related to travel and time periods. The questionnaire had two types of question sets, one related to age, gender, income, type of training, and type of employment with independent variables. A second set of dependent variables illustrated respondents' intentions and opinions on respondents' perceptions and intentions to travel in the next period.

The structure of the sample is represented in Figure 2, where the structure can be observed by age, sex, degree of training, income, and employment.
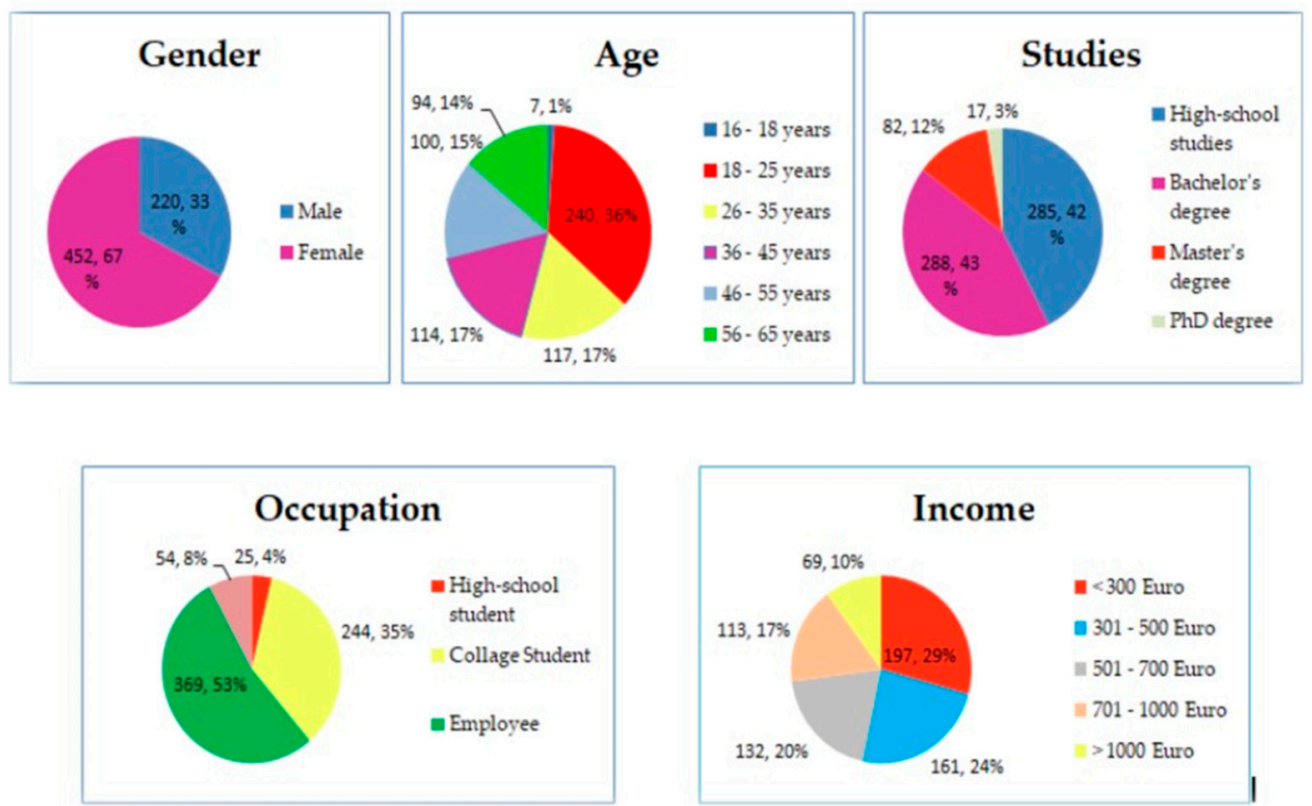

Figure 2. Sample structure. Source: Own processing based on data obtained from the centralization of questionnaire responses.

The characteristics of the studied population are summarized in Table 1 . Out of the total of 672 respondents, $67.30 \%$ are women (452 people) and the remaining $32.70 \%$ are men (220 people). Most of the respondents, $35.70 \%$ (240 people), are aged between 18 and 25 years, $17.40 \%$ (117 people) are aged between 26 and 35 years, 17\% (114 people) are aged between 36 and 45 years, 14.90\% (100 people) are aged between 46 and 55 years, 14\% are respondents over 55 years but up to 65 years, and the smallest part, 1\%, were respondents of 16-18 years.

The structure according to the degree of education is represented as follows: in almost equal proportions, $42.40 \%$ (285 people) high school studies and $42.90 \%$ (288 people) bachelor's degree, followed by master's degree, $12.20 \%$ (82 people), and $\mathrm{PhD}$ degree, $2.50 \%$ (17 people).

In total, 54.90\% (369 people) are employees, and the rest are either college students, $33.30 \%$ (244 people); freelance workers, $8.00 \%$ (54 people); or high school students, $3.70 \%$ (25 people).

Out of the total of 672 respondents, $29.30 \%$ have a monthly income of less than 300 EUR, only $10.30 \%$ (69 people) have a monthly income of more than $1000 \mathrm{EUR}, 24 \%$ have 301-500 EUR, 19.60\% have 501-700 EUR, and 16.80\% have 701-1000 EUR. 
Table 1. Characteristics of the studied population.

\begin{tabular}{cccc}
\hline Specification & & $\mathbf{n = 6 7 2}$ & $\%$ \\
\hline \multirow{2}{*}{ Sex } & Male & 220 & $32.70 \%$ \\
& Female & 452 & $67.30 \%$ \\
\hline \multirow{2}{*}{ Age } & $16-18$ years & 7 & $1 \%$ \\
& $18-25$ years & 240 & $35.70 \%$ \\
& $26-35$ years & 117 & $17.40 \%$ \\
& $36-45$ years & 114 & $17 \%$ \\
& $46-55$ years & 100 & $14.90 \%$ \\
& $56-65$ years & 94 & $14 \%$ \\
\hline \multirow{3}{*}{ Studies } & High school studies & 285 & $42.40 \%$ \\
& Bachelor's degree & 288 & $42.90 \%$ \\
& Master's degree & 82 & $12.20 \%$ \\
& PhD degree & 17 & $2.50 \%$ \\
\hline \multirow{2}{*}{ Occupation } & High-school student & 25 & $3.70 \%$ \\
& College Student & 244 & $33.30 \%$ \\
& Employee & 369 & $54.90 \%$ \\
& Freelance worker & 54 & $8.00 \%$ \\
\hline Income & $<300$ EUR & 197 & $29.30 \%$ \\
& 301-500 EUR & 161 & $24 \%$ \\
& $501-700$ EUR & 132 & $19.60 \%$ \\
& $701-1000$ EUR & 113 & $16.80 \%$ \\
& $>1000$ EUR & 69 & \\
& & & $10.30 \%$ \\
\hline
\end{tabular}

Source: Own research.

Figure 3 shows the answers to the first question: "How often did you use to travel?" (By travel, we mean tourism, business, health, shopping, etc.). This aims at establishing how often respondents traveled in the last 2 years before the health crisis.

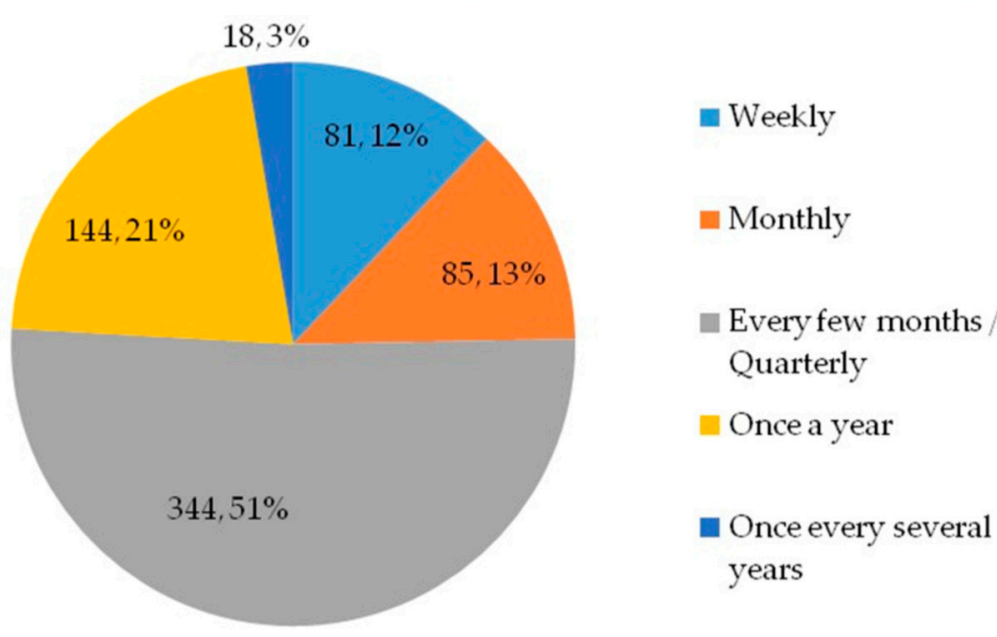

Figure 3. Frequency of travel. Source: Own Research.

From this figure that consolidates the answers related to the frequency of travel, it is observed that most of the respondents, $51 \%$ (344 people), had the habit of traveling once every few months/quarterly. A total of $21 \%$ (144 people) traveled once a year, $13 \%$ of respondents traveled monthly, and only $3 \%$ answered that they traveled once every few years. This consolidation indicates that over $75 \%$ of respondents traveled for various purposes several times a year before the outbreak of the COVID-19 pandemic. 
The second question, "Where have you traveled in the last 2 years?" aims at establishing the destination of the trip. The consolidation of the answers to this question is found in Figure 4 and showed that most, 52.5\% (353 people), preferred to travel within borders, $5.8 \%$ of respondents preferred international travel, and $41.7 \%$ chose both destinations.

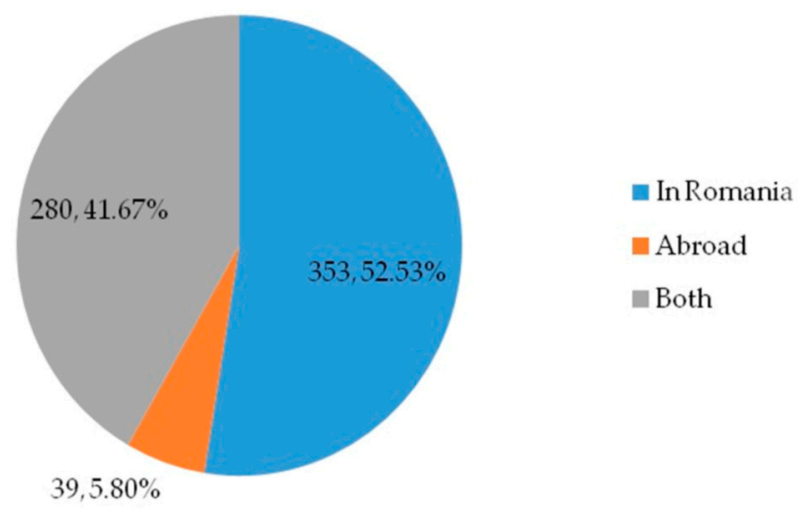

Figure 4. Travel destination of the last two years. Source: Own research.

Question 3, "To what extent, on a scale of 1 to 5 (1 means not at all, and 5 very much), do you think you will travel in 2021 in the current pandemic context?", aimed at establishing the intention to travel in the current conditions. The consolidation of the answers is illustrated in Figure 5 and highlights the fact that most, 31.99\% (215 people), are undecided about travelling in the next period. The clear intention to travel was represented by $19.79 \%$ (133 people), and 7.14\% (48 people) do not want to travel in the next period.

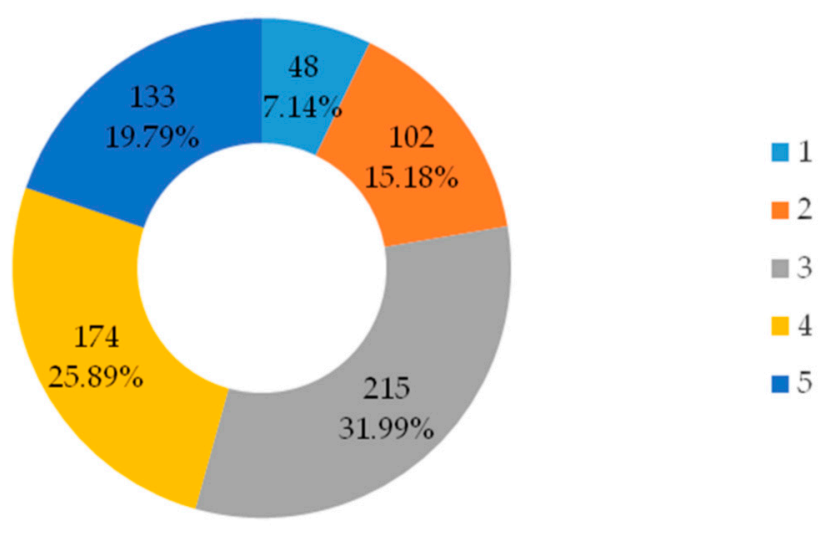

Figure 5. Intention to travel. Source: Own research.

The fourth question is "Which travel destinations do you find safer in the current context?", and it aims at determining the perception of the travel destination in the pandemic context. It can be seen from Figure 6, which illustrates the answers to the fourth question, that most of the respondents, $52.23 \%$ (351 people), consider that for them, the safest destination for travel for tourism is Romania. For the safety of international travel, 37.50\% (252 people) appear, and 10.27\% (69 people) consider that travel in the current health crisis is safe. 


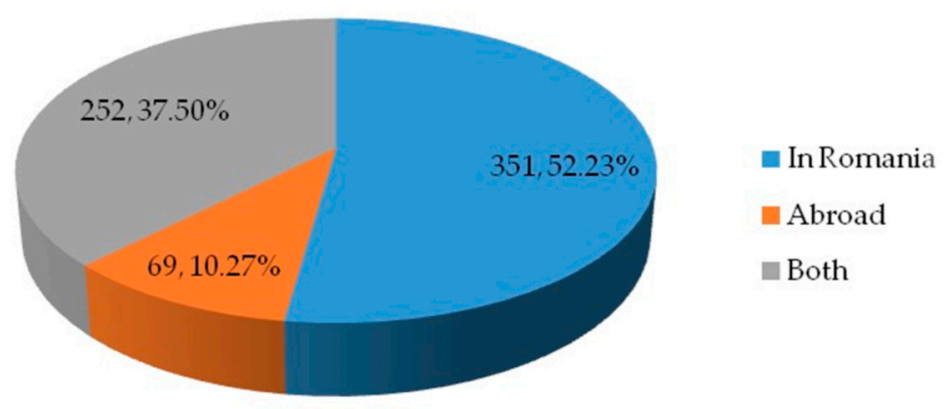

Figure 6. Perceived safer destination. Source: Own research.

The fifth question, "Where do you want to travel to Romania?", aimed at identifying travel preferences for destinations in the country. We were able to identify, according to Figure 7, which consolidates the answers to this question, that the final destination preferred by 446 respondents is the mountainous area followed by the seaside area (397 people), the destinations of large cities (235 people), and spa destinations (108 people).

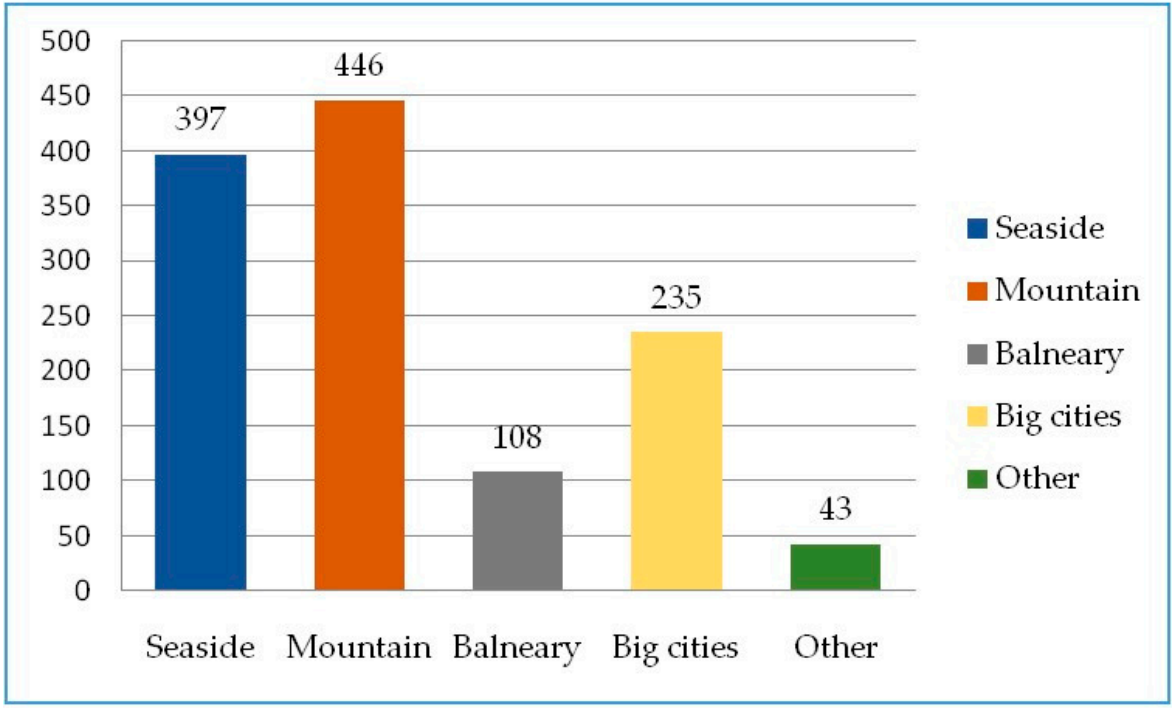

Figure 7. Travel preferences for destinations in Romania. Source: Own research.

The sixth question, "Where do you find information about your trip to Romania?", aims at establishing the sources from which tourists are informed about their next trip in their homeland. The answers to this question are consolidated in Figure 8. Most respondents, $64.14 \%$ (431 people), as expected during the COVID-19 pandemic, are informed exclusively by Internet sources, only $3.57 \%$ ( 24 people) are informed only from travel agencies, and 207 people (30.80\%) are informed by both sources. 


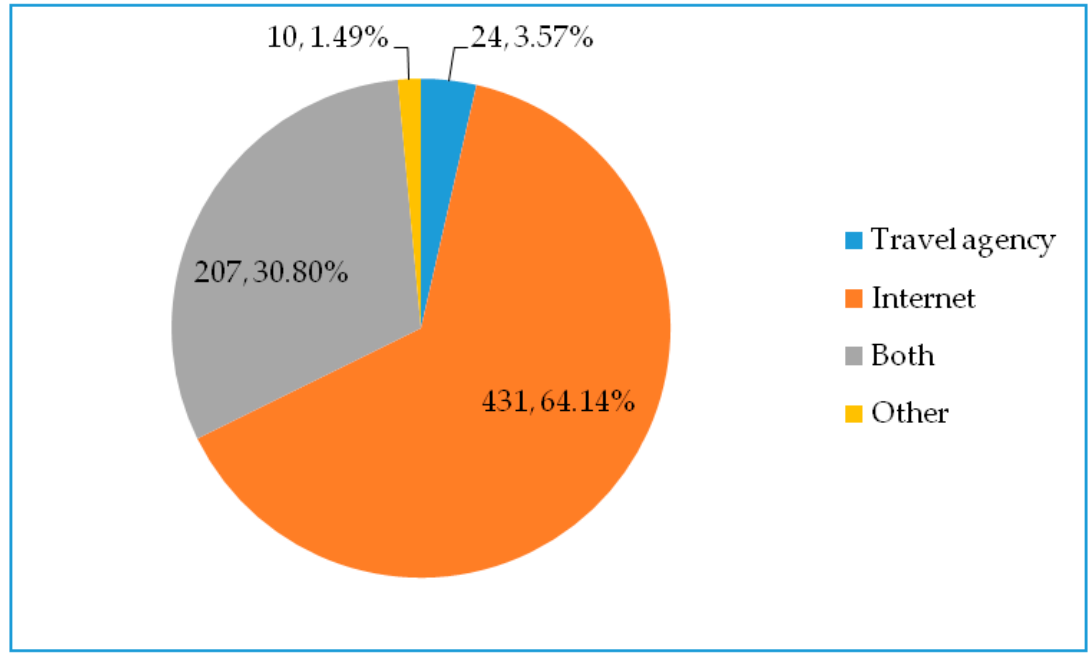

Figure 8. Sources of information for destinations in Romania. Source: Own research.

The seventh question, "Where do you find information about traveling abroad?", aims at identifying the sources from which travelers are informed for trips abroad. According to Figure 9, where the answers to this question are consolidated for international travel, the respondents have as their first source the Internet, with 543 people. The second source of information was the travel agency, with 268 answers, and 109 people are informed directly by the embassy of the destination country.

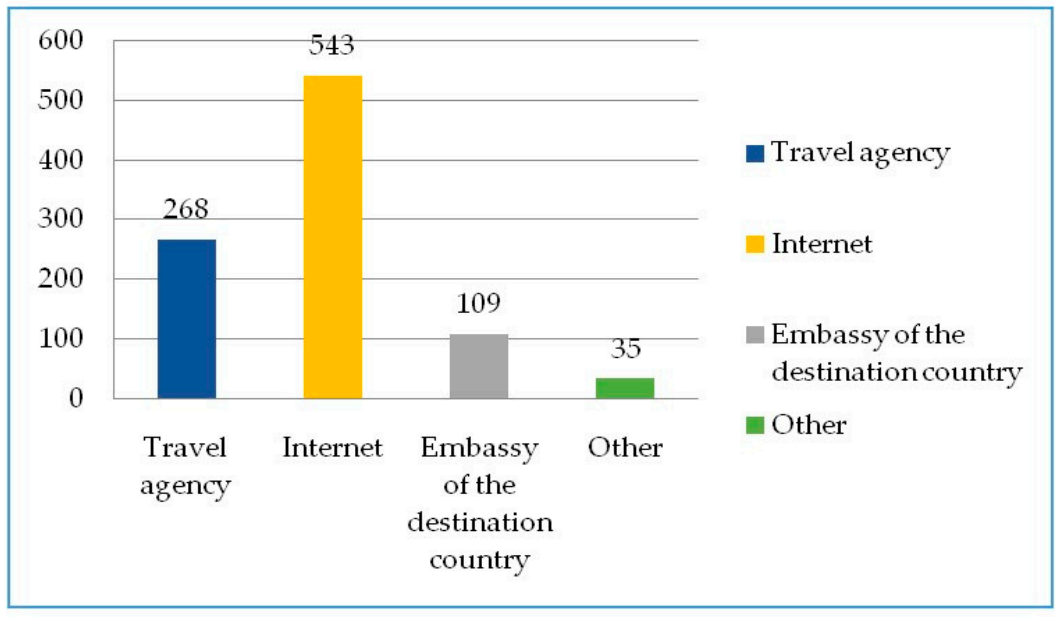

Figure 9. Sources of information for destinations abroad. Source: Own research.

The eighth question, "Assess in terms of importance the conditions that the tourist destination must meet during the health crisis caused by the SARS-CoV-2 virus: on a scale from 1 to 5 ( 1 very little important, and 5 very much important)", aims at determining the importance that travelers give to the conditions that must meet the tourist destination during the pandemic. The answers to question number 8 are consolidated in Figure 10. This question aims at prioritizing the perception of the importance of meeting the conditions imposed by the current health crisis in the field of accommodations and food; the conditions to be met by HoReCa staff and other tourists; or the incidence of infection with COVID19 at the tourist destination. From this consolidation, the results are that the respondents emphasize on the observance of sanitary protection norms in the accommodation units (372 respondents gave a maximum of importance to accommodation, and 376 respondents gave a maximum of importance to food/restaurants). 


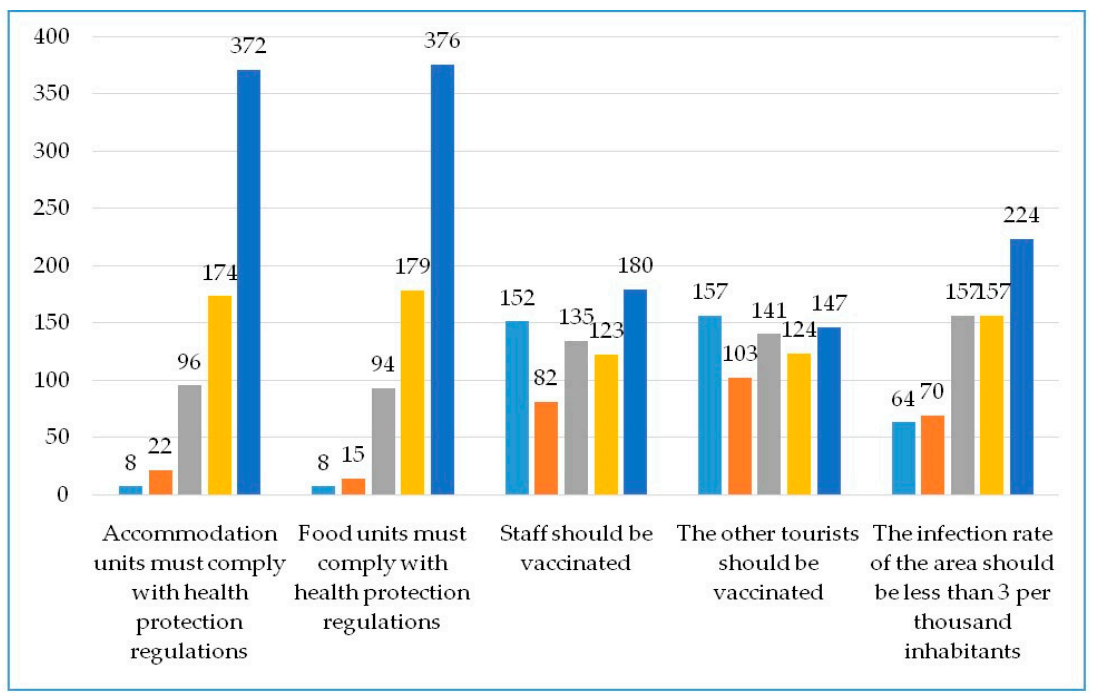

Figure 10. Assessment according to the importance of the conditions that the tourist destination must meet during the health crisis caused by the SARS-CoV-2 virus. Source: Own research.

For this question, one of the most commonly used scaling methods was used, namely the semantic differential. In this case, the investigated person is asked to express his or her opinions about the stimulus under investigation (in this case: the conditions that must meet the tourist destination during the health crisis caused by the SARS-CoV-2 virus), which is characterized by a series of pairs of bipolar attributes. Between the two adjective components of each pair was inserted a scale, with five levels, the direction and intensity of the person's opinion being established based on the level that the respondent indicates on the respective scale. The evaluation of the assessments involves the calculation of the average assessments, starting from grade 5 attributed to the very important assessments, then decreasing to grade 1 for assessments that are not at all important. The centralization of the calculated scores can be observed in Table 2.

Table 2. The importance of the conditions that the tourist destination must meet during the health crisis caused by the SARS-CoV-2 virus.

\begin{tabular}{|c|c|c|c|c|c|}
\hline \multirow[b]{2}{*}{ Scale } & \multicolumn{5}{|c|}{$\begin{array}{c}\text { Assessment according to the Importance of the Conditions that the Tourist Destination Must Meet during the } \\
\text { Health Crisis Caused by the SARS-CoV-2 Virus: } \\
\text { On a Scale of } 1 \text { to } 5 \text { (1 Very Unimportant and } 5 \text { Very Important) }\end{array}$} \\
\hline & $\begin{array}{l}\text { Accommodation Units } \\
\text { Must Comply with } \\
\text { Health Protection } \\
\text { Regulations }\end{array}$ & $\begin{array}{l}\text { Food Units Must } \\
\text { Comply with Health } \\
\text { Protection Regulations }\end{array}$ & $\begin{array}{l}\text { Staff Should } \\
\text { Be Vaccinated }\end{array}$ & $\begin{array}{l}\text { The Other Tourists } \\
\text { Should Be Vaccinated }\end{array}$ & $\begin{array}{l}\text { The Infection Rate } \\
\text { of the Area Should } \\
\text { Be Less than } 3 \text { per } \\
1000 \text { Inhabitants }\end{array}$ \\
\hline 1 & 8 & 8 & 152 & 157 & 64 \\
\hline 2 & 22 & 15 & 82 & 103 & 70 \\
\hline 3 & 96 & 94 & 135 & 141 & 157 \\
\hline 4 & 174 & 179 & 123 & 124 & 157 \\
\hline 5 & 372 & 376 & 180 & 147 & 224 \\
\hline Total & 672 & 672 & 672 & 672 & 672 \\
\hline Score & 4.30 & 4.34 & 3.14 & 3.01 & 3.60 \\
\hline
\end{tabular}

In this research, five pairs of attributes were used, the average points obtained for each pair were joined, obtaining a graphical image of the sample views illustrated in Figure 11. 


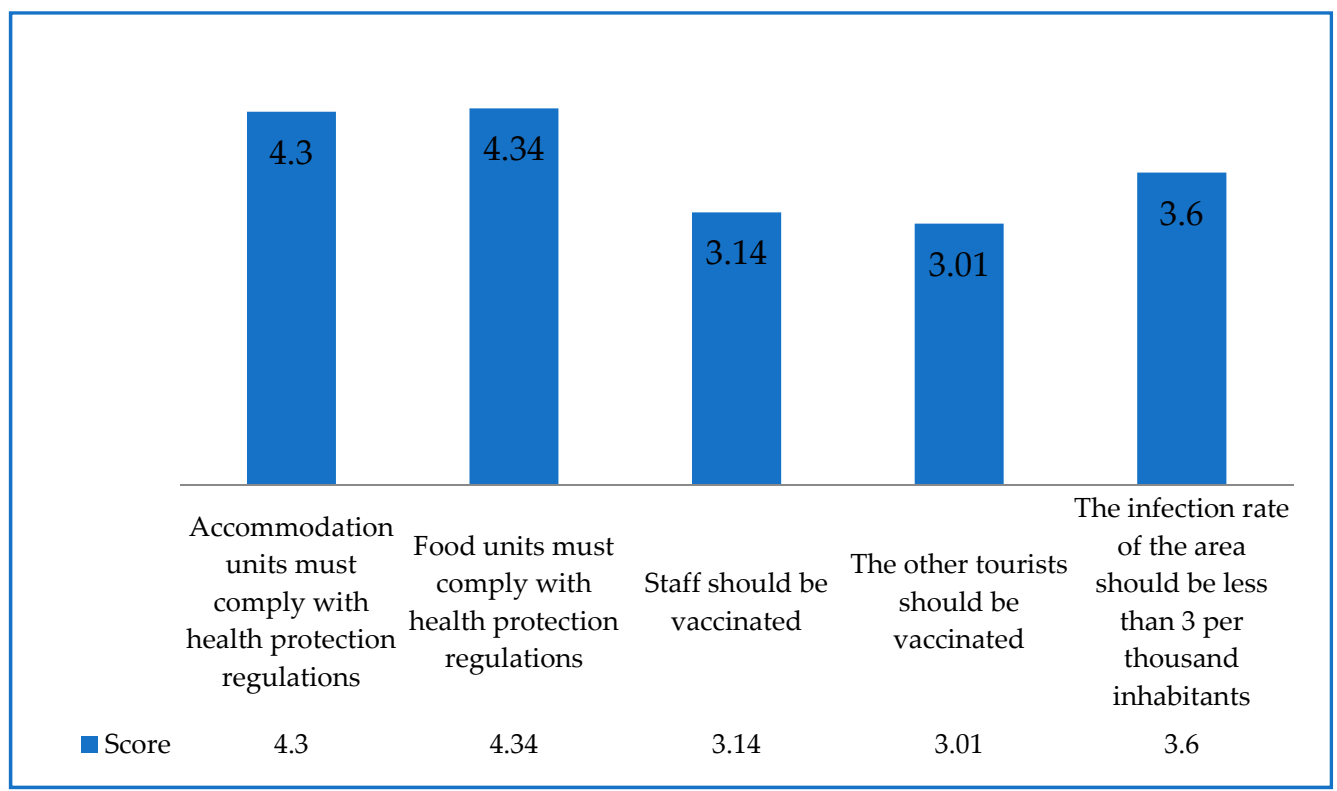

Figure 11. Scores obtained regarding the importance of the fulfillment given to the conditions that the tourist destination must meet during the health crisis caused by the SARS-CoV-2 virus. Source: Own research.

The highest score of 4.34 is held by the attribute "Food units must comply with health protection regulations", followed by the attribute "Accommodation units must comply with health protection regulations" with the score 4.30, and the lowest score of 3.01 is recorded for the attribute "The other tourists should be vaccinated".

Question 9, "When you answer these questions, what is the incidence of SARS-CoV2 virus infection in your place of residence?", aimed at determining the circumstances of COVID-19 infection expressed by incidence, i.e., the number of infections per 1000 people. Figure 12 illustrates the answers to this question.

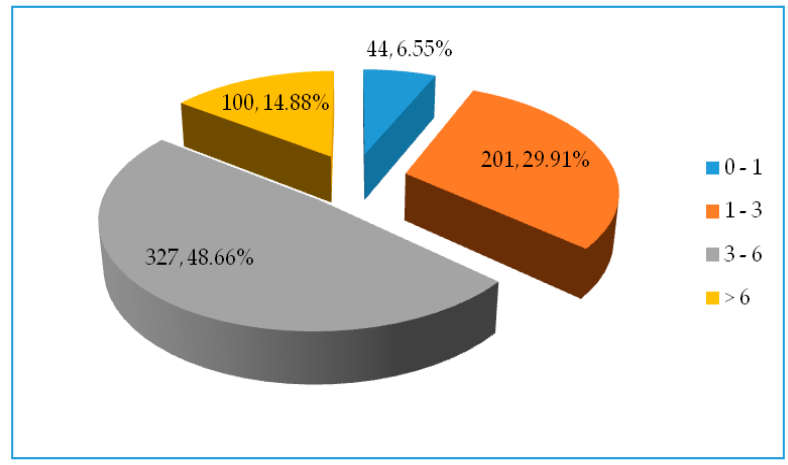

Figure 12. Incidence of COVID-19 infection in respondents' localities. Source: Own research.

It should be noted that most of the respondents, $48.66 \%$ ( 327 people), come from areas where their place of residence is under the incidence of 3-6\%, 29.91\% (201 people) with an incidence of $1-3 \%, 14.88 \%$ (100 people) with an incidence of more than $6 \%$, and only $6.55 \%$ (44 people) in an area with an incidence of less than $1 \%$.

Question 10, "When you answer these questions, what situation are you in?", aimed at determining the situation of the respondents regarding vaccination against infection with the new coronavirus. The situation is represented in Figure 13. 


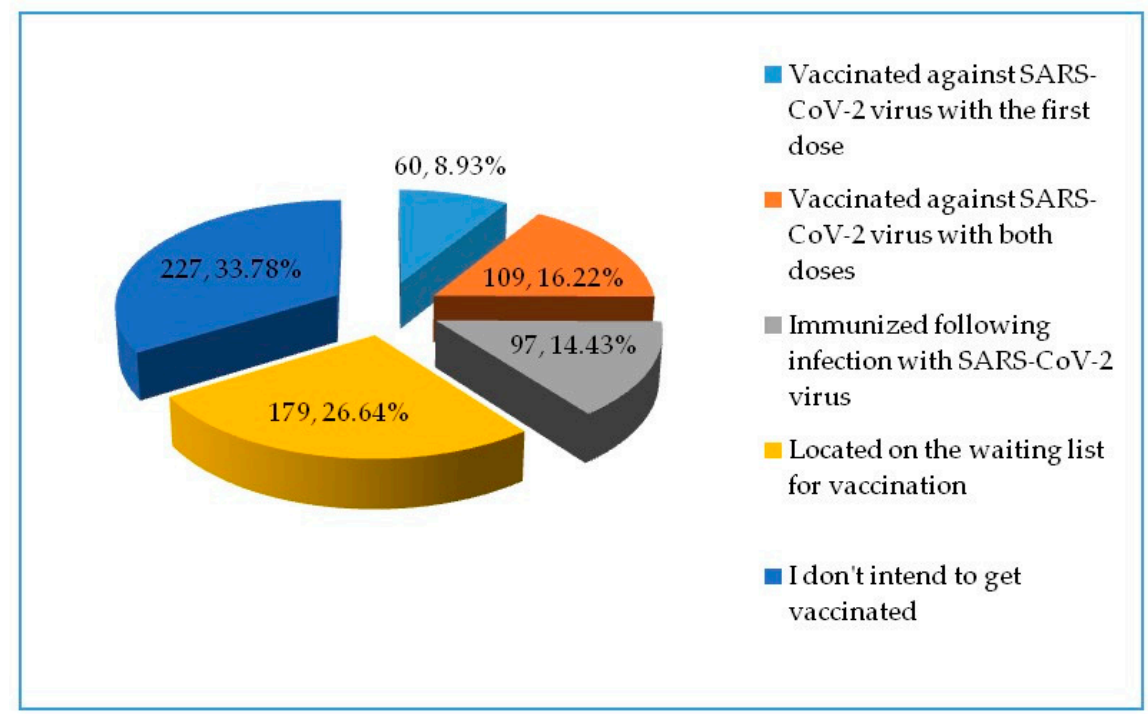

Figure 13. Situation of respondents regarding vaccination against infection with the new coronavirus. Source: Own research.

It is found that a large part of the respondents, $66.22 \%$, are under the spectrum of total or partial immunization: either they were naturally immunized by infection, $14.43 \%$, or they are immune by vaccination with both doses, $16.22 \%$; vaccinated with the first dose, $8.93 \%$; or waiting to enter the vaccination schedule. However, there are $33.78 \%$ respondents (227 people) who do not want to be vaccinated against the new coronavirus.

Question 11, "What do you think, in your view, traveling for recreational or leisure purposes in the next period marked by the health crisis caused by the SARS-CoV-2 virus? (max. 100 words)", is an open-ended question that allows respondents to provide longer answers and allows them to provide answers in their own words. This question aims at determining the respondents' opinions on traveling during the COVID-19 pandemic. Being an open-ended question, not all interviewees answered, or there were many very short answers, such as "ok", "k", or more or less cheerful emoticons. The most common ideas used by the respondents are presented in Table 3.

Analyzing each answer to this question, it was found that there are a number of keywords used more than 10 times. In Figure 14, these words are consolidated: the words "restrictions", "rules", and "protection" stand out.

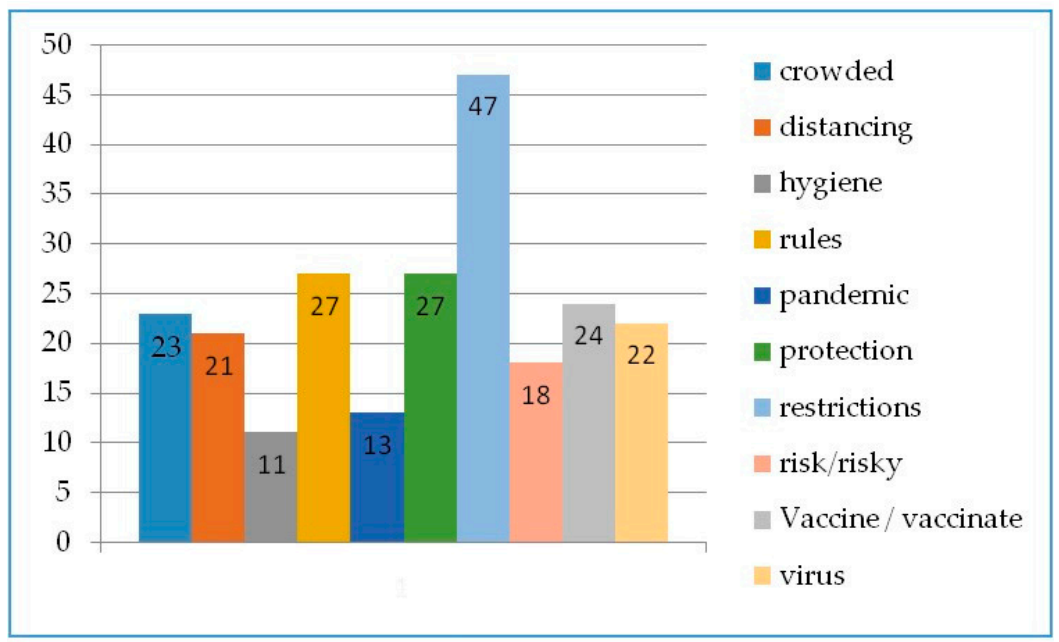

Figure 14. The most frequently used words in the answers related to the perception of travel for tourism purposes in the next period marked by the health crisis caused by the SARS-CoV-2 virus. Source: Own research. 
Corroborating the information obtained based on the questionnaire and illustrated in Table 3 and Figure 14, some ideas are highlighted in the respondents' perception that revolve around travel restrictions, protection against virus, regulations in force during the health crisis, and, last but not least, protection in various forms and vaccination.

Table 3. Perception of traveling for recreational or leisure purposes in the next period marked by the health crisis caused by the SARS-CoV-2 virus.

\begin{tabular}{|c|c|}
\hline \multicolumn{2}{|r|}{ Perception of Travel for Tourism in the Next Period Marked by the Health Crisis Caused by the SARS-CoV-2 Virus } \\
\hline 1 & $\begin{array}{l}\text { A short trip, max 3-4 nights, probably in an area where a negative PCR test is required for my safety and that of those } \\
\text { around me, where safety measures are followed. Accommodation in a hotel with restaurant. If I leave the country, } \\
\text { I would opt for a country that does not involve quarantine when returning to Romania (e.g., Turkey). }\end{array}$ \\
\hline 2 & $\begin{array}{l}\text { I consider that in the next period it will be difficult to travel if the appropriate measures are not taken in the tourism } \\
\text { areas. The person who plans the trip wants to have information regarding the created conditions. }\end{array}$ \\
\hline 3 & $\begin{array}{l}\text { Sure enough, if I am vaccinated. I consider that people will travel more to Romania, not because of the fact that better } \\
\text { sanitation conditions are offered, but because they are closer to home, know the pandemic situation better in their } \\
\text { country, they can be more easily informed about the spread of the virus, and the costs of a possible postponement of the } \\
\text { holiday involve lower costs than if they were traveling abroad. The trip will have a more recreational purpose, limited } \\
\text { to a duration of 1-2 days, at a distance not very far from the residence, in mountainous or coastal areas. }\end{array}$ \\
\hline 4 & $\begin{array}{l}\text { In this context, especially the current one with the new wave of infections, this tourism year will not be a very good one, } \\
\text { probably like last year. }\end{array}$ \\
\hline 5 & $\begin{array}{c}\text { For me, the vision does not change. Vacation means relaxation and good mood. I will not go on vacation to places } \\
\text { where stress and restrictions are high. I will go on vacation to places where everything is normal or as close to normal as } \\
\text { possible. }\end{array}$ \\
\hline 6 & Much more limited in all respects, with far fewer attractions and visits and probably a greater openness towards nature. \\
\hline 7 & $\begin{array}{l}\text { Hello! The only difference from past travel is compliance with COVID-19 infection prevention measures. As long as } \\
\text { through your own protection you protect others, everything is fine. Thank you! }\end{array}$ \\
\hline 8 & I will tend to travel to places less frequented by other tourists. \\
\hline 9 & $\begin{array}{l}\text { There will still be a very large number of restrictions that will limit the possibilities of travel and the variety of activities } \\
\text { that could have been carried out under normal conditions. }\end{array}$ \\
\hline 10 & $\begin{array}{l}\text { I hope that the location I have chosen respects all the sanitary protection norms. It will certainly be a holiday with more } \\
\text { restrictions than before, but I consider it for the good of all humankind. The words that will define this holiday will be } \\
\text { caution/carefulness, but not fear/panic. }\end{array}$ \\
\hline
\end{tabular}

Source: Elaborated by authors.

The respondents identified in their perception a number of tendencies in the hospitality domain that can generally be described as being related to safety and hygiene, and they have become particularly important in the pandemic context, as the world adapts to the virus and efforts to limit the spread. They perceive these concepts as being a priority for hotels, restaurants, bars, and cafes. There is a tendency for respondents to perceive travel within safer borders, and this is primarily because information about the rules imposed by the spread of the virus is more accessible to them, and any change is perceived immediately.

Respondents perceive travel in wilder mountain areas as safer than coastal, beach, and seafront areas where congestion cannot be avoided. It is also perceived as safer, in the conditions of the global coronavirus pandemic, to travel in small groups and as much as possible only with family members. Destinations in nature are perceived as safer because this form of tourism will allow them to maintain social distance and to discover nature, which they could not benefit from, as traffic restrictions have been more severe.

During the study, respondents expressed their concern about the existing situation regarding coronavirus by answering the question, "To what extent, on a scale of 1 to 5 ( 1 means not at all, and 5 very much), do you think you will travel in 2021 in the current pandemic context?", and the survey highlighted the concern expressed in the current health crisis by the fact that most respondents are either undecided or do not want to travel in the current conditions. 
The respondents were given the opportunity to express their views on whether they believe that tourism is responsible for the spread of the virus or feel safe staying at a hotel, answering the question, "Assess in terms of importance the conditions that the tourist destination must meet during the health crisis caused by the SARS-CoV-2 virus: on a scale from 1 to 5 ( 1 means not at all, and 5 very much)", and the highest scores were recorded for meeting the safety conditions for the basic elements of the tourism industry, namely accommodations and food.

The question, "How do you see traveling for recreational or leisure purposes in the next period marked by the health crisis caused by the SARS-CoV-2 virus? (max. 100 words)", gave the respondents the opportunity to assess if traveling for recreational or leisure purposes during this period is ethical, and their answers were varied, creating a comprehensive picture on perception. Respondents consider it ethical to travel during this period if the pandemic context is also certain.

We will further establish the connection between the variables of perception upon traveling. The most common parametric measure of correlation is the Pearson product moment correlation coefficient.

The variables of perception upon traveling used to establish the correlation are those in the questionnaire, namely:

- Willingness to travel in 2021 in the context of the current pandemic;

- Accommodation units must comply with health protection regulations;

- Food units must comply with health protection regulations;

- $\quad$ Staff should be vaccinated;

- The other tourists should be vaccinated.

Table 4 illustrates the Pearson correlation coefficients between these variables.

Table 4. Pearson correlation coefficient between travel perception variables in the current pandemic context.

\begin{tabular}{|c|c|c|c|c|c|c|}
\hline & $\begin{array}{l}\text { Willingness } \\
\text { to Travel in } \\
2021 \text { in the } \\
\text { Context of } \\
\text { the Current } \\
\text { Pandemic }\end{array}$ & $\begin{array}{l}\text { Accommodation } \\
\text { Units Must } \\
\text { Comply with } \\
\text { Health } \\
\text { Protection } \\
\text { Regulations }\end{array}$ & $\begin{array}{l}\text { Food Units } \\
\text { Must } \\
\text { Comply with } \\
\text { Health } \\
\text { Protection } \\
\text { Regulations }\end{array}$ & $\begin{array}{l}\text { Staff Should } \\
\text { Be } \\
\text { Vaccinated }\end{array}$ & $\begin{array}{l}\text { The Other } \\
\text { Tourists } \\
\text { Should Be } \\
\text { Vaccinated }\end{array}$ & $\begin{array}{l}\text { The Infection } \\
\text { Rate of the } \\
\text { Area Should } \\
\text { Be Less than } \\
3 \text { per } 1000 \text { In- } \\
\text { habitants }\end{array}$ \\
\hline $\begin{array}{l}\text { Willingness to travel in } \\
2021 \text { in the context of the } \\
\text { current pandemic }\end{array}$ & 1 & & & & & \\
\hline $\begin{array}{l}\text { Accommodation units } \\
\text { must comply with health } \\
\text { protection regulations }\end{array}$ & 0.332352888 & 1 & & & & \\
\hline $\begin{array}{c}\text { Food units must comply } \\
\text { with health protection } \\
\text { regulations }\end{array}$ & 0.331445732 & 0.999739439 & 1 & & & \\
\hline $\begin{array}{l}\text { Staff should be } \\
\text { vaccinated }\end{array}$ & -0.031015798 & 0.651172313 & 0.658750115 & 1 & & \\
\hline $\begin{array}{c}\text { The other tourists should } \\
\text { be vaccinated }\end{array}$ & -0.152135172 & 0.237840675 & 0.248349161 & 0.888324657 & 1 & \\
\hline $\begin{array}{l}\text { The infection rate of the } \\
\text { area should be less than } \\
3 \text { per } 1000 \text { inhabitants }\end{array}$ & 0.620205722 & 0.936497524 & 0.936784478 & 0.611383558 & 0.257381129 & 1 \\
\hline
\end{tabular}

It can be noticed that the strongest correlations with a Pearson coefficient higher than +0.5 are achieved in most situations: "The infection rate of the area should be less than 3 per thousand inhabitants" is strongly correlated with "Willingness to travel in 2021 in the context of the current pandemic" (0.620205722); "The infection rate of the area should be less than 3 per thousand inhabitants" is strongly correlated with "Accommodation units 
must comply with health protection regulations" (0.936497524); and "The infection rate of the area should be less than 3 per thousand inhabitants" is strongly correlated with "Food units must comply with health protection regulations" (0.936784478). It can be observed that an infection rate higher than 3 per 1000 inhabitants is correlated with all the variables considered in the perception of travel during the COVID-19 pandemic.

Additionally, high correlations are registered between the variables "Food units must comply with health protection regulations" and "Accommodation units must comply with health protection regulations" (0.999739439), and "Staff should be vaccinated" and "Accommodation units must comply with health protection regulations" or "Food units must comply with health protection regulations", with a correlation coefficient higher than 0.65 .

All variables are related to correlation coefficients other than " 0 ".

\section{Discussion}

There is an emphasis in this period of health crisis on the fact that tourism will be supported by demand, because the offer is still valid with varied programs. This study highlights that the desire to travel is still valid but is still bound by the norms of social distance and travel restrictions both within the country and abroad.

The interpretation of the questionnaire shows that the respondents used to travel often; over $75 \%$ of the answers indicate that they used to travel more than once a year. The main destination for traveling was Romania.

Under the current conditions, full of unforeseen restrictions for the most part, over $45 \%$ of respondents expressed their intention to travel. Additionally, for the next period, destinations in the country are preferred; travelers are still wary of traveling to other countries due to travel restrictions imposed at the border of some states. From the open answers, it was highlighted that less crowded, wilder, and closer to nature destinations are preferred.

Additionally, from the analysis of the questionnaire, it emerged that the respondents are interested in the conditions imposed in the context of the COVID-19 pandemic, the top interest being "Food units must comply with health protection regulations", which is almost equal, depending on the calculated score, with "Accommodation units must comply with health protection regulations".

Regarding information accessed by tourists, $64.1 \%$ prefer the Internet for trips in Romania, and $80.8 \%$ of the respondents still choose the Internet as the main source of information for trips abroad. The Internet is an easy way to book through various platforms, such as Booking and Airbnb, but also to view reviews from other tourists, which they consider very important.

In fact, the Internet, through the sites and pages of the main institutions of the state that fight against the virus, is a reliable source of information on traffic rules, incidents in the locality, and travel conditions. Going through a period of the third wave of infection, the majority of respondents, $63.6 \%$, are in the locality of the red scenario, with the incidence of infections with SARS-CoV-2 virus being greater than 3 per 1000 .

An important element in the fight against the virus and the global pandemic is vaccination. This is also representative in the tourism sector. Respondents to our questionnaire are eager to travel again, and $25.1 \%$ of them are already immunized by vaccination, $14.4 \%$ are immunized from virus infection, and $26.6 \%$ are on the waiting list to be vaccinated. Thus, we note that $66.1 \%$ of respondents are eligible and ready to travel in the near future.

Considering not only the results of the survey but also the indicators of tourist movement in Romania, the degree to which the tourist industry was affected can be observed. The basic indicators, which can indicate the size of traffic, tourist arrivals, Romanian tourist arrivals, and foreign tourist arrivals, are analyzed comparatively, as in Table 5. It can be observed that the greatest decreases in number of arrivals are recorded for both domestic and international tourism in April and May, with decreases of over 95\%. 
Table 5. Arrivals of tourists accommodated in the structure of tourists' reception by tourist type, monthly [73].

\begin{tabular}{|c|c|c|c|c|c|c|c|c|c|c|c|c|c|}
\hline $\begin{array}{l}\text { Type of } \\
\text { Tourists }\end{array}$ & Year & Jan & Feb & Mar & Apr & May & Jun & Jul & Aug & Sep & Oct & Nov & Dec \\
\hline \multirow{3}{*}{ Total } & 2019 & 758,439 & 758,826 & 800,361 & 885,822 & $1,103,937$ & $1,308,897$ & $1,651,335$ & $1,869,383$ & $1,312,488$ & 108,1817 & 902,837 & 834,614 \\
\hline & 2020 & 796,256 & 724,445 & 242,105 & 16,855 & 34,569 & 333,950 & 917,778 & $1,301,411$ & 794,451 & 493,101 & 338,728 & 341,752 \\
\hline & $\% \Delta$ & 4.99 & -4.53 & -69.75 & -98.10 & -96.87 & -74.49 & -44.42 & -30.38 & -39.47 & -54.42 & -62.48 & -59.05 \\
\hline \multirow{3}{*}{ Domestic } & 2019 & 618,621 & 623,876 & 631,270 & 681,807 & 831,301 & $1,022,762$ & $1,350,243$ & $1,557,077$ & 102,4725 & 843,025 & 726,382 & 685,959 \\
\hline & 2020 & 668,636 & 603,642 & 207,885 & 15,503 & 33262 & 320,964 & 887,688 & $1,269,122$ & 761,701 & 468,419 & 319,992 & 325,322 \\
\hline & $\% \Delta$ & 8.08 & -3.24 & -67.07 & -97.73 & -96.00 & -68.62 & -34.26 & -18.49 & -25.67 & -44.44 & -55.95 & -52.57 \\
\hline \multirow{3}{*}{ International } & 2019 & 139,818 & 134,950 & 169,091 & 204,015 & 272,636 & 286,135 & 301,092 & 312,306 & 287,763 & 238,792 & 176,455 & 148,655 \\
\hline & 2020 & 127,620 & 120,803 & 34,220 & 1352 & 1307 & 12,986 & 30,090 & 32,289 & 32,750 & 24,682 & 18,736 & 16,430 \\
\hline & $\% \Delta$ & -8.72 & -10.48 & -79.76 & -99.34 & -99.52 & -95.46 & -90.01 & -89.66 & -88.62 & -89.66 & -89.38 & -88.95 \\
\hline
\end{tabular}

Source: Processing by the authors of data from the National Institute of Statistics Romania, https://insse.ro/cms/sites/default/files/field/ publicatii/frecventarea_structurilor_de_primire_turistica_cu_functiuni_de_cazare_trim_4_2020.pdf, accessed on 15 April 2021.

Overall, at the level of the country, the number of arrivals registered a decrease of over $52 \%$ (see Table 6). The flow of international tourists decreased by $83 \%$ in 2020 compared to 2019. Among the national destinations, the smallest decrease was registered by the coastal destinations as $21.53 \%$, and the biggest loss was registered by Bucharest along with the rest of the cities (three times higher) as $62.41 \%$.

Table 6. Arrivals of tourists accommodated in the structure of tourists' reception by tourist destinations and tourist type [73].

\begin{tabular}{|c|c|c|c|c|}
\hline Touristic Destinations & $\begin{array}{l}\text { Type of } \\
\text { Tourists }\end{array}$ & 2019 & 2020 & $\% \Delta$ \\
\hline \multirow{3}{*}{ Total } & Total & $13,374,943$ & $6,398,642$ & -52.16 \\
\hline & Domestic & $10,691,195$ & $5,944,775$ & -44.40 \\
\hline & International & $2,683,748$ & 453,867 & -83.09 \\
\hline \multirow{3}{*}{ Spas } & Total & $1,133,359$ & 601,326 & -46.94 \\
\hline & Domestic & $1,098,706$ & 595,762 & -45.78 \\
\hline & International & 34,653 & 5564 & -83.94 \\
\hline \multirow{3}{*}{$\begin{array}{l}\text { Seaside. excluding } \\
\text { Constanta town }\end{array}$} & Total & $1,153,682$ & 905,266 & -21.53 \\
\hline & Domestic & $1,119,401$ & 899,104 & -19.68 \\
\hline & International & 34,281 & 6162 & -82.03 \\
\hline \multirow{3}{*}{ Mountain resorts } & Total & $2,305,517$ & $1,295,105$ & -43.83 \\
\hline & Domestic & $2,109,378$ & $1,269,109$ & -39.83 \\
\hline & International & 196,139 & 25,996 & -86.75 \\
\hline \multirow{3}{*}{$\begin{array}{c}\text { Danube Delta area. } \\
\text { including Tulcea town }\end{array}$} & Total & 166,411 & 118,325 & -28.90 \\
\hline & Domestic & 146,006 & 116,797 & -20.01 \\
\hline & International & 20,405 & 1528 & -92.51 \\
\hline \multirow{3}{*}{$\begin{array}{l}\text { Bucharest and county } \\
\text { residence town. } \\
\text { excluding Tulcea }\end{array}$} & Total & $6,275,835$ & $2,359,090$ & -62.41 \\
\hline & Domestic & $4,209,530$ & $1,994,058$ & -52.63 \\
\hline & International & $2,066,305$ & 365,032 & -82.33 \\
\hline \multirow{3}{*}{$\begin{array}{l}\text { Other localities and } \\
\text { touristic routes }\end{array}$} & Total & $2,340,139$ & $1,119,530$ & -52.16 \\
\hline & Domestic & $2,008,174$ & $1,069,945$ & -46.72 \\
\hline & International & 331,965 & 49,585 & -85.06 \\
\hline
\end{tabular}

Source: Processing by the authors of data from the National Institute of Statistics Romania https://insse.ro/cms/sites/default/files/field/publicatii/frecventarea_structurilor_de_primire_turistica_cu_ functiuni_de_cazare_trim_4_2020.pdf, accessed on 15 April 2021.

In the statistical analysis of this phenomenon, it must be considered that January and February were not subject to pandemic restrictions; in March, April, and May, the Romanian territory was subject to lockdown, and all activities in HoReCa were closed. Tourism was able to resume its activity.

Using the statistical analysis " $t$-Test: Paired Two Sample for Means", we have analyzed the last months of 2021 compared to the last months of 2019. We have analyzed only 
national tourism because, as it was observed, the inflows of international tourists are almost insignificant and depended on the conditions imposed by the countries of origin. The results are illustrated in Table 7.

Table 7. " $t$-Test: Paired Two Sample for Means" statistical analysis of arrivals for the last 7 months of 2019 and 2020.

\begin{tabular}{ccc}
\hline & Year 2019 & Year 2020 \\
Mean & $1,030,024.714$ & $621,886.8571$ \\
Variance & $1.04326 \times 10^{11}$ & $1.33718 \times 10^{11}$ \\
Observations & 7 & 7 \\
Pearson Correlation & 0.917342298 & \\
Hypothesized Mean Difference & 0 & \\
df & 6 & \\
$\mathrm{P}(\mathrm{T} \leq \mathrm{t})$ one-tail & 7.390696935 & \\
$\mathrm{t}$ Critical one-tail & 0.000157468 & \\
$\mathrm{P}(\mathrm{T} \leq \mathrm{t})$ two-tail & 1.943180274 & \\
$\mathrm{t}$ Critical two-tail & 0.000314936 & \\
\hline
\end{tabular}

Source: Own processing based on data obtained from data centralization.

In this analysis, $\mathrm{P}(\mathrm{T} \leq \mathrm{t})$ two-tail $(0.000157468)$ gives the probability that the absolute value of the statistic $t$ Stat (7390) is observed, which is higher in absolute value than the critical $t$ value (2446). As the $p$ value is less than our alpha, 0.05 , we reject the null hypothesis that there is no significant difference in the average of each sample. The Pearson correlation (0.917) indicates that the two variables are closely correlated.

\section{Conclusions}

This paper aims at highlighting the perception of tourists regarding traveling for recreational or leisure purposes in times of health crisis. The COVID-19 pandemic did not discriminate, so that all companies in the tourism sector and all travel destinations were massively affected by unprecedented travel restrictions and felt economic and social blockages.

Tourism activity was severely affected due to the significant decrease in tourist arrivals and the progressive decrease in tourism revenues, which led to the temporary or permanent closure of several associated activities. In addition to hotels, restaurants and related activities were also severely affected, such as travel agencies, transport companies, and larger or smaller shops in tourist destinations. All these phenomena also influenced the tourism demand.

In order to highlight the way in which the trip is seen for future reference during the health crisis of COVID-19 in general, but also in particular in Romania, we used several research methods to lead us, as much as possible, to relevant results. If, in the beginning, when the COVID-19 pandemic broke out, people were afraid to travel because the evolution of SARS-CoV-2 infections was unknown, now, more than a year after the pandemic was declared, people are eager to travel. Of course, the desire to travel is dependent on the degree of freedom at the borders, the incidence of infections, the degree of vaccination, etc. However, previous studies have noted that travel motivation among young people can be non-self-centered, such as traveling to experience nature and culture, while others may be linked together by hedonic and escape motives [11], such as trips for fun and to take a break from everyday life, they will probably be the first to express their desire to travel after the threat of COVID-19 infection has diminished. Studies related to the motivation of travel have confirmed that the mood of tourists influences them to travel and visit new places.

Thus, understanding the perception of travel and the impulses that motivate tourists to travel can benefit specialists in the tourism industry but also those who research the evolution of actions to impose restrictions in the current pandemic context. This research related to the perception of travel in the current health crisis along with previous studies related to the motivation [32] to travel can be the basis of planning in tourism, and the 
decision makers must react to this challenge with a strong presence on the Internet and social media, implementing smart strategies which could serve as new motivations for travel from younger generations.

The analysis of the answers in the questionnaire revealed that most of the respondents intend to travel in the next period. While personal budgets will become tighter and tighter, the desire to go out and explore will only increase. It is expected that more people will want to travel nationally, thus supporting local economies by exploring their own cities or regions in the country that offer tourist attractions. Locations in unknown areas have the opportunity to increase the number of visitors, and less frequented tourist destinations can benefit from demand, given the preference for less crowded places.

Their answers highlighted the intention of travelers to opt for destinations in nature because this form of tourism will allow them to maintain social distance and access discovery and contact with nature, which they have not been able to benefit from in recent months.

The pandemic has highlighted the harmful effects of tourism and mass industry on the planet and the natural environments in which we live. Humankind is expected to turn its attention to sustainable, environmentally friendly travel deals with a minor impact on the local community. Travelers will opt for experiences that promote the health and well-being of people and the planet.

This paper is subject to study limitations but may also suggest additional lines of research. The study concludes with more limitations than other studies due to limited data and the volatility of those that exist. During this research, the conjunctural data related to the degree of infection, the lifting or imposition of new traffic restrictions, the increase in the number of people vaccinated were changed, therefore some of the questions in the survey state: "When you answer these questions ....". In addition, the outbreak is still active, creating serious health and economic problems around the world, so that further study of the perception of traveling in new situations, in different parts of the country or in the world, can provide much useful information. This study may be continued in the future, with interest for researchers expanding the geographical area or pursuing tourist activity following this study, or it can serve as a starting point for a comparative analysis of the perception of travelling during the period of site restrictions, with information on the same subject in the coming years, given that the same population selected from the active population. This comparison can create a complete picture of tourists' perceptions of traveling for recreational or leisure purposes in times affected by a health crisis. Such research is important because perceptions of travel destinations in times of crisis are important for predicting future tourism demands and developing appropriate recovery strategies.

Author Contributions: The authors worked together on this research, but, per structure: Conceptualization: A.-G.T. and C.-M.C.; Formal Analysis: C.-M.C., C.-G.S., and L.-G.T.; Investigation: E.Ş.M. and F.C.; Methodology: F.C. and A.-G.T.; Resources: C.-M.C., C.-G.S., and A.-G.T.; Software: F.C. and D.M.R.; Supervision L.-G.T. and E.S..M.; Validation: A.-G.T.; Writing—original sketch: A.-G.T., C.-M.C., and F.C.; Writing-review and editing: D.M.R., C.-M.C., and A.-G.T. All authors have read and agreed to the published version of the manuscript.

Funding: This research received no external funding. This work was financed by Danubius University from Galati, Romania.

Informed Consent Statement: The collection of information through the questionnaire was done anonymously, without requiring respondents to specify personal information.

Data Availability Statement: The data presented in this study are available on request from the corresponding author. The data are not publicly available due to privacy.

Acknowledgments: This work was financed by Danubius University from Galati.

Conflicts of Interest: The authors declare no conflict of interest. 


\section{References}

1. European Council of the European Union. Available online: https://www.consilium.europa.eu/ro/policies/coronavirus/ (accessed on 1 April 2021).

2. Walmsley, T.; Rose, A.; Wei, D. The Impacts of the Coronavirus on the Economy of the United States. Econ. Disasters Clim. Chang. 2021, 5, 1-52. [CrossRef] [PubMed]

3. Goodrich, J.N. September 11, 2001 Attack on America: Impact on Tourism Security. J. Travel Tour. Mark. 2002, 11, 1-12. [CrossRef]

4. McKercher, B.; Chon, K.K.S. The Over-Reaction to SARS and the Collapse of Asian Tourism. Ann. Tour. Res. 2004, 31, 716-719. [CrossRef] [PubMed]

5. Schmude, J.; Karl, M.; Weber, F. Tourism and Terrorism: Economic impact of terrorist attacks on the tourism industry. The example of the destination of Paris. Z. Wirtsch. 2020, 64, 88-102. [CrossRef]

6. UNWTO. World Tourism Organization and International Labour Organization Economic Crisis, International Tourism Decline and Its Impact on the Poor; UNWTO: Madrid, Spain, 2013. [CrossRef]

7. Worldometer. Available online: https://www.worldometers.info/coronavirus/ (accessed on 4 April 2021).

8. UNWTO World Tourism Barometer (English Version). Available online: https://doi.org/10.18111/wtobarometereng (accessed on 4 April 2021).

9. Steg, L.; Perlaviciute, G.; Van Der Werff, E.; Lurvink, J. The Significance of Hedonic Values for Environmentally Relevant Attitudes, Preferences, and Actions. Environ. Behav. 2014, 46, 163-192. [CrossRef]

10. Wang, X.; Van der Werff, E.; Bouman, T.; Harder, M.K.; Steg, L. I Am vs. We Are: How Biospheric Values and Environmental Identity of Individuals and Groups Can Influence Pro-environmental Behaviour. Front. Psychol. 2021, 12. [CrossRef]

11. Cavagnaro, E.; Staffieri, S.; Carrieri, A.; Burns, K.; Chen, N.; Fermani, A. Profiling for sustainable tourism: Young travellers' self-transcendence values and motivations. Eur. J. Tour. Res. 2021, 28, 2810.

12. Bratić, M.; Radivojević, A.; Stojiljković, N.; Simović, O.; Juvan, E.; Lesjak, M.; Podovšovnik, E. Should I Stay or Should I Go? Tourists' COVID-19 Risk Perception and Vacation Behavior Shift. Sustainability 2021, 13, 3573. [CrossRef]

13. UNWTO, COVID-19 Related Travel Restrictions A Global Review For Tourism 9th Report as of 8 March 2021. Available online: https:/ / webunwto.s3.eu-west-1.amazonaws.com/s3fs-public/2021-03/210309-Travel-Restrictions.pdf (accessed on 4 April 2021).

14. Gössling, S.; Scott, D.; Hall, C.M. Pandemics, tourism and global change: A rapid assessment of COVID-19. J. Sustain. Tour. 2020, 29, 1-20. [CrossRef]

15. Uğur, N.G.; Akbıyık, A. Impacts of COVID-19 on global tourism industry: A cross-regional comparison. Tour. Manag. Perspect. 2020, 36, 100744. [CrossRef]

16. Worldometer. Available online: https://www.worldometers.info/coronavirus/\#countries (accessed on 7 April 2021).

17. Davahli, M.R.; Karwowski, W.; Sonmez, S.; Apostolopoulos, Y. IThe Hospitality Industry in the Face of the COVID-19 Pandemic: Current Topics and Research Methods. Int. J. Environ. Res. Public Health 2020, 17, 7366. [CrossRef]

18. Pusca, C.A. Should We Share Rights and Obligations with Artificial Intelligence Robots? In Lecture Notes of the Institute for Computer Sciences, Social Informatics and Telecommunications Engineering; Santos, H., Pereira, G., Budde, M., Lopes, S., Nikolic, P., Eds.; Springer: Cham, Switzerland, 2020; Volume 323, pp. 412-419.

19. Belzunegui-Eraso, A.; Erro-Garcés, A. Teleworking in the Context of the Covid-19 Crisis. Sustenability 2020, 12, 3662. [CrossRef]

20. Radulescu, C.; Ladaru, G.-R.; Burlacu, S.; Constantin, F.; Ioanăs, C.; Petre, I. Impact of the COVID-19 Pandemic on the Romanian Labor Market. Sustainability 2020, 13, 271. [CrossRef]

21. Arimura, M.; Ha, T.V.; Okumura, K.; Asada, T. Changes in urban mobility in Sapporo city, Japan due to the Covid-19 emergency declarations. Transp. Res. Interdiscip. Perspect. 2020, 7, 100212. [CrossRef]

22. Kim, K. Impacts of COVID-19 on transportation: Summary and synthesis of interdisciplinary research. Transp. Res. Interdiscip. Perspect. 2021, 9, 100305. [PubMed]

23. Orro, A.; Novales, M.; Monteagudo, Á.; Pérez-López, J.-B.; Bugarín, M. Impact on City Bus Transit Services of the COVID19 Lockdown and Return to the New Normal: The Case of A Coruña (Spain). Sustainability 2020, 12, 7206. [CrossRef]

24. Barbieri, D.M.; Lou, B.; Passavanti, M.; Hui, C.; Hoff, I.; Lessa, D.A.; Sikka, G.; Chang, K.; Gupta, A.; Fang, K.; et al. Impact of COVID-19 pandemic on mobility in ten countries and associated perceived risk for all transport modes. PLoS ONE 2021, 16, e0245886. [CrossRef] [PubMed]

25. Bartle, J.; Lutte, R.; Leuenberger, D. Sustainability and Air Freight Transportation: Lessons from the Global Pandemic. Sustainability 2021, 13, 3738. [CrossRef]

26. Sun, X.; Wandelt, S.; Zhang, A. How did COVID-19 impact air transportation? A first peek through the lens of complex networks. J. Air Transp. Manag. 2020, 89, 101928. [CrossRef] [PubMed]

27. Abu-Rayash, A.; Dincer, I. Analysis of mobility trends during the COVID-19 coronavirus pandemic: Exploring the impacts on global aviation and travel in selected cities. Energy Res. Soc. Sci. 2020, 68, 101693. [CrossRef]

28. International Air Transport Association [IATA]. Annu. Rev. 2020. Available online: https://www.iata.org/contentassets/c81222 d96c9a4e0bb4ff6ced0126f0bb/iata-annual-review-2020.pdf (accessed on 15 April 2021).

29. Institutul National de Statistica (INS) Transportul Aeroportuar de Pasageri şi Mărfuri în Anul 2020/National Institute of Statistics (INS) Irport Passenger and Freight Transport in 2020. Available online: https:/ /insse.ro/cms/sites/default/files/field/publicatii/ transportul_aeroportuar_de_pasageri_si_marfuri_in_anul_2020_0.pdf (accessed on 15 April 2021). 
30. Kaushal, V.; Srivastava, S. Hospitality and tourism industry amid COVID-19 pandemic: Perspectives on challenges and learnings from India. Int. J. Hosp. Manag. 2021, 92, 102707. [CrossRef] [PubMed]

31. Sibi, P.S.; Das, A.; Ashraf, M. Changing Paradigms of Travel Motivations Post COVID-19. Int. J. Manag. 2020, 11, 489-500.

32. Yousaf, A.; Amin, I.; Santos, J.A.C. Tourists' Motivations to Travel: A Theoretical Perspective on the Existing Literature. Tour. Hosp. Manag. 2018, 24, 197-211. [CrossRef]

33. Roman, M.; Niedziółka, A.; Krasnodębski, A. Respondents' Involvement in Tourist Activities at the Time of the COVID19 Pandemic. Sustainability 2020, 12, 9610. [CrossRef]

34. Păvăluc, C.; Brînză, G.; Anichiti, A.; Butnaru, G.I. COVID-19 pandemic and its effects on the tourism sector. CES Work. Pap. 2020, $12,111-122$.

35. Cutler, S.Q.; Carmichael, B. The dimensions of the tourist experience. In The Tourism and Leisure Experience: Consumer and Managerial Perspectives; Morgan, M., Lugosi, P., Ritchie, B., Eds.; Channel View Publications: Bristol, UK, 2010 ; pp. 3-26.

36. Jászberényi, M.; Miskolczi, M. Danube Cruise Tourism as a Niche Product-An Overview of the Current Supply and Potential. Sustainability 2020, 12, 4598. [CrossRef]

37. Ito, H.; Hanaoka, S.; Kawasaki, T. The cruise industry and the COVID-19 outbreak. Transp. Res. Interdiscip. Perspect. 2020, 5, 100136. [CrossRef]

38. Saarinen, J. Critical sustainability: Setting the limits to growth and responsibility in tourism. Sustainability 2014, 6, 1-17. [CrossRef]

39. Persson-Fischer, U.; Liu, S. The Impact of a Global Crisis on Areas and Topics of Tourism Research. Sustainability 2021, 13, 906. [CrossRef]

40. Sigala, M. Tourism and COVID-19: Impacts and implications for advancing and resetting industry and research. J. Bus. Res. 2020, 117, 312-321. [CrossRef] [PubMed]

41. Dorobăț, M.L.; Dobrescu, C.M. The Anthropic Impact in the North-Western Side of Leaota Mountains. J. Curr. Trends Nat. Sci. 2016, 5, 63-72.

42. Lapointe, D. Reconnecting tourism after COVID-19: The paradox of alterity in tourism areas. Tour. Geogr. 2020, 22, 633-638. [CrossRef]

43. Reitsamer, B.F.; Brunner-Sperdin, A. Tourist destination perception and well-being. J. Vacat. Mark. 2017, 23, 55-72. [CrossRef]

44. Hurley, S. Perception And Action: Alternative Views. Synthese 2001, 129, 3-40. [CrossRef]

45. Matiza, T. Post-COVID-19 crisis travel behaviour: Towards mitigating the effects of perceived risk. J. Tour. Futur. 2020. ahead-ofprint. [CrossRef]

46. Majeed, S.; Zhou, Z.; Lu, C.; Ramkissoon, H. Online Tourism Information and Tourist Behavior: A Structural Equation Modeling Analysis Based on a Self-Administered Survey. Front. Psychol. 2020, 11, 599. [CrossRef] [PubMed]

47. European Commission. Eurobarometer The EP and the Expectations of European Citizens. Resilience and Recovery: Public Opinion One Year into the Pandemic. Available online: https://www.europarl.europa.eu/at-your-service/files/be-heard/ eurobarometer/2021/spring-2021-survey/report.pdf (accessed on 11 June 2021).

48. Seth Borko, Wouter Geerts, Haixia Wang The Travel Industry Turned Upside Down: Insights, Analysis and Actions for Travel Executives, McKinsey and Company, Skift Research. 2020. Available online: https://www.mckinsey.com/ \{\}/media/mckinsey/ industries / travel\%20logistics\%20and\%20infrastructure/our\%20insights/the \%20travel $\% 20$ industry $\% 20$ turned $\% 20$ upside $\% 20$ down $\% 20$ insights $\% 20$ analysis $\% 20$ and $\% 20$ actions $\% 20$ for $\% 20$ travel $\% 20$ executives / the-travel-industry-turned-upside-downinsights-analysis-and-actions-for-travel-executives.pdf (accessed on 11 June 2021).

49. Lopes, S.D.F. Polytechnic Institute of Cávado and Ave (Portugal) Destination image: Origins, Developments and Implications. PASOS. Rev. Turismo Patrim. Cult. 2011, 9, 305-315. [CrossRef]

50. Cristinel Petrişor Constantin, Cercetări De Marketing În Cadrul Destinaţiei Turistice Braşov, Teza De Abilitare/ Marketing Research Within The Brasov Tourist Destination, Habilitation Thesis, Brasov. 2016. Available online: https://www.unitbv.ro/ documente/cercetare/doctorat-postdoctorat/abilitare/teze-de-abilitare/constantin-cristinel/05-Constantin-Teza_abilitare_ RO.pdf (accessed on 12 June 2021).

51. Rindrasih, E. Tourist's Perceived Risk and Image of the Destinations Prone to Natural Disasters: The Case of Bali and Yogyakarta, Indonesia. Humaniora 2018, 30, 192-203. [CrossRef]

52. Di Marino, E. The Strategic Dimension of Destination Image: An Analysis of the French Riviera Image from the Italian Tourists' Perceptions. Ph.D. Thesis, University of Naples “Federico II", 2008. Available online: http://www.esade.edu/cedit/pdfs/ papers/pdf10.pdf (accessed on 12 June 2021).

53. Radic, A.; Law, R.; Lück, M.; Kang, H.; Ariza-Montes, A.; Arjona-Fuentes, J.; Han, H. Apocalypse Now or Overreaction to Coronavirus: The Global Cruise Tourism Industry Crisis. Sustainability 2020, 12, 6968. [CrossRef]

54. Mestanza-Ramón, C.; Jiménez-Caballero, J. Nature Tourism on the Colombian-Ecuadorian Amazonian Border: History, Current Situation, and Challenges. Sustainability 2021, 13, 4432. [CrossRef]

55. Ali, Y.; Shah, Z.A.; Khan, A.U. Post-terrorism image recovery of tourist destination: A qualitative approach using Fuzzy-VIKOR. J. Tour. Anal. 2018, 25, 129-153. [CrossRef]

56. Rasoolimanesh, S.; Seyfi, S.; Rastegar, R.; Hall, C. Destination image during the COVID-19 pandemic and future travel behavior: The moderating role of past experience. J. Destin. Mark. Manag. 2021, 21, 100620. [CrossRef]

57. Chen, H.; Zuo, Y.; Law, R.; Zhang, M. Improving the Tourist's Perception of the Tourist Destinations Image: An Analysis of Chinese Kung Fu Film and Television. Sustainability 2021, 13, 3875. [CrossRef] 
58. Xu, J.; Loi, K.I.; Kong, W.H. The effects of perceptions of flagshipness and iconicity on word of mouth for attractions and destinations. J. Vacat. Mark. 2019, 26, 96-107. [CrossRef]

59. Cahyanto, I.; Wiblishauser, M.; Pennington-Gray, L.; Schroeder, A. The dynamics of travel avoidance: The case of Ebola in the U.S. Tour. Manag. Perspect. 2016, 20, 195-203. [CrossRef]

60. Leggat, P.; Brown, L.; Aitken, M.P.; Speare, R. Level of Concern and Precaution Taking Among Australians Regarding Travel During Pandemic (H1N1) 2009: Results From the 2009 Queensland Social Survey. J. Travel Med. 2010, 17, 291-295. [CrossRef]

61. Pine, R.; McKercher, B. The impact of SARS on Hong Kong's tourism industry. Int. J. Contemp. Hosp. Manag. 2004, 16, 139-143. [CrossRef]

62. Schneider, C.R.; Dryhurst, S.; Kerr, J.; Freeman, A.L.J.; Recchia, G.; Spiegelhalter, D.; van der Linden, S. COVID-19 risk perception A longitudinal analysis of its predictors and associations with health protective behaviours in the United Kingdom. J. Risk Res. 2021, 24, 294-313. [CrossRef]

63. Neuburger, L.; Egger, R. Travel risk perception and travel behaviour during the COVID-19 pandemic 2020: A case study of the DACH region. Curr. Issues Tour. 2021, 24, 1003-1016. [CrossRef]

64. Chua, B.-L.; Al-Ansi, A.; Lee, M.J.; Han, H. Impact of health risk perception on avoidance of international travel in the wake of a pandemic. Curr. Issues Tour. 2020, 24, 985-1002. [CrossRef]

65. Lopes, H.D.S.; Remoaldo, P.; Ribeiro, V.; Martín-Vide, J. Effects of the COVID-19 Pandemic on Tourist Risk Perceptions-The Case Study of Porto. Sustainability 2021, 13, 6399. [CrossRef]

66. European Commission. Behavioural Changes in Tourism in Times of COVID-19. Available online: https://s3platform.jrc.ec. europa.eu/documents / 20182/392265/Behavioural+changes+in+tourism+in+times+of+COVID-19/059ea958-6696-467a-8507 -2e8617a4b86 (accessed on 15 April 2021).

67. Naderifar, M.; Goli, H.; Ghaljaei, F. Snowball Sampling: A Purposeful Method of Sampling in Qualitative Research. Strides Dev. Med Educ. 2017, 14. [CrossRef]

68. Kirchherr, J.; Charles, K. Enhancing the sample diversity of snowball samples: Recommendations from a research project on anti-dam movements in Southeast Asia. PLoS ONE 2018, 13, e0201710. [CrossRef]

69. Dragan, I.M.; Isaic-Maniu, A. Snowball Sampling Completion. J. Stud. Soc. Sci. 2013, 5. Available online: http://infinitypress. info/index.php/jsss/article/view/355/207 (accessed on 20 April 2021).

70. Noy, C. Sampling Knowledge: The Hermeneutics of Snowball Sampling in Qualitative Research. Int. J. Soc. Res. Methodol. 2008, 11,327-344. [CrossRef]

71. Garg, R. Methodology for research I. Indian J. Anaesth. 2016, 60, 640-645. [CrossRef] [PubMed]

72. Adam, A.M. Sample Size Determination in Survey Research. J. Sci. Res. Rep. 2020, 26, 90-97. [CrossRef]

73. National Institute of Statistics Romania. Available online: https://insse.ro/cms/sites/default/files/field/publicatii/ frecventarea_structurilor_de_primire_turistica_cu_functiuni_de_cazare_trim_4_2020.pdf (accessed on 21 April 2021). 